\title{
3. PLIOCENE TO QUATERNARY CALCAREOUS NANNOFOSSIL BIOSTRATIGRAPHY OF THE ARCTIC OCEAN, WITH REFERENCE TO LATE PLIOCENE GLACIATION ${ }^{1}$
}

\author{
Tokiyuki Sato $^{2}$ and Koji Kameo ${ }^{3}$
}

\begin{abstract}
Calcareous nannofossil assemblages from the samples in Holes 910A, 910C, and 911A were studied in order to estimate the age of the sediments drilled at the Yermak Plateau in the Arctic Ocean. Although the abundance and species diversity of calcareous nannofossil flora were poor, eight of twelve Quaternary calcareous nannofossil events were detected in Hole 911A. This indicates that the Quaternary datum planes defined by Takayama and Sato (1987) are applicable to the Arctic Ocean.

The late Pliocene new datum plane A, defined by the floral change from Reticulofenestra spp. (small) assemblage to Coccolithus pelagicus assemblage, is placed in the late Gauss Normal Epoch in the successions at both the Japan Sea side of Japan and at the Arctic Ocean. This horizon is also assigned to that of increased dropstones in Holes 910C and 911A. These facts indicate that the datum plane A in the late Gauss Normal Epoch is strongly related to heavy glaciation in the high northern latitudes.
\end{abstract}

\section{INTRODUCTION}

Takayama and Sato (1987) investigated calcareous nannofossils from Cenozoic sediments recovered from the North Atlantic during Deep Sea Drilling Project (DSDP) Leg 94, and they recognized a total of 12 calcareous nannofossil datums in the Quaternary. Sato et al. (1988; 1991) and Sato and Takayama (1992) also studied the calcareous nannofossil assemblage of the uppermost Cenozoic sediments from the Indian Ocean, both Pacific and Japan Sea sides of Japan, and the Pliocene/Pleistocene boundary stratotype in Italy, and showed that the Quaternary datum planes recognized in the North Atlantic Ocean were applicable to the low- to high-latitude regions in not only the Atlantic Ocean, but also the Japan Sea, Pacific Ocean, Indian Ocean, and Mediterranean Sea.

During Ocean Drilling Program Leg 151, seven sites were drilled in the Norwegian-Greenland Sea and the Arctic Ocean in an effort to clarify the timing and development of polar cooling and to establish the temporal and spatial variation of sea-ice distribution, the glacial history of the circum-arctic, Greenland, and Northern Europe, and the history of ice rafted debris (IRD) sedimentation in the Arctic (Fig. 1).

In this report, we describe in detail the calcareous nannofossil assemblages and their stratigraphic changes in Holes 910A, 910C, and 911A, located in the Yermak Plateau in the Arctic Ocean (Fig. 1; Table 1). On the basis of their results, we also discuss the biostratigraphic utility of calcareous nannofossil datum planes defined by Takaya$\mathrm{ma}$ and Sato (1987) and the relationship between calcareous nannofossil assemblages, polar cooling, and the sea-ice distribution.

\section{METHOD}

Each sample was processed by a smear slide preparation method for calcareous nannofossil study. The microslide (size of coverslip is

'Thiede, J., Myhre, A.M., Firth, J.V., Johnson, G.L., and Ruddiman, W.F. (Eds.). 1996. Proc. ODP, Sci. Results, 151: College Station, TX (Ocean Drilling Program). ${ }^{2}$ Institute of Applied Earth Sciences, Mining College, Akita University, Tegata Gakuencho 1-1, Akita 010, Japan. toki@ quartet.ipc.akita-u.ac.jp

${ }^{3}$ Technical Research Center, Teikoku Oil Co., Ltd. 23-30, Kita-Karasuyama 9 Chome, Setagaya-Ku, Tokyo 157, Japan.
$18 \mathrm{~mm} \times 18 \mathrm{~mm}$ ) was observed under the binocular polarizing microscope with an oil-immersion objective at a magnification of $1,500 \times$. As the abundance of calcareous nannofossils is rare to barren and is not sufficient for quantitative analysis in most samples, we emphasize the qualitative analysis of distribution of each species throughout upper Cenozoic sequences.

Range charts have been prepared for all samples examined and show the presence of calcareous nannofossil species in each sample. Among three holes, the total number of calcareous nannofossil specimens in the samples from Hole 911A is designated in Table 2 by using one of following codes: $\mathrm{A}=$ abundant (more than 200 specimens in a smear slide); $\mathrm{C}=$ common ( 60 to 200 specimens in a smear slide); $\mathrm{R}=$ rare (less than 60 specimens in a smear slide); $\mathrm{B}=$ barren (no specimens are found in a smear slide).

\section{PLIOCENE TO QUATERNARY CALCAREOUS NANNOFOSSIL DATUMS}

Many Quaternary calcareous nannofossil events were classified by recent studies mainly based on the analysis of deep-sea cores (Gartner, 1977; Rio, 1982; Rio et al., 1990, 1991; Takayama and Sato, 1987; Raffi et al., 1993; Matsuoka and Okada, 1989). In the North Atlantic Ocean, Takayama and Sato (1987) investigated calcareous nannofossil floras of the Cenozoic sediments recovered from the bottom of the Northeast Atlantic Ocean during DSDP Leg 94. They recognized a total of 12 calcareous nannofossil datums in the Quaternary sediments. These datums were correlated with the magnetostratigraphy established by Clement and Robinson (1987), and ages for all the datums were estimated by interpolation between magnetic reversals. Subsequently, Sato (1989) restudied the calcareous nannofossil assemblages at Hole 610A and recognized one additional datum in the Quaternary. The relations between magnetic reversals and these calcareous nannofossil datums were summarized by Sato et al. (1991), and a total of 13 datums in the Quaternary were numbered from 1 to 13 in descending stratigraphic order.

However, a more recent geomagnetochronology has been published by Cande and Kent (1992). Therefore, we have recalculated the ages of the late Pliocene to Quaternary calcareous nannofossil datums of Sato et al. (1991), based on the relationships between the calcareous nannofossil stratigraphy of Leg 94 (Holes 606, 607, 609, and 610 A studied by Takayama and Sato, 1987 and Sato, 1989), the mag- 


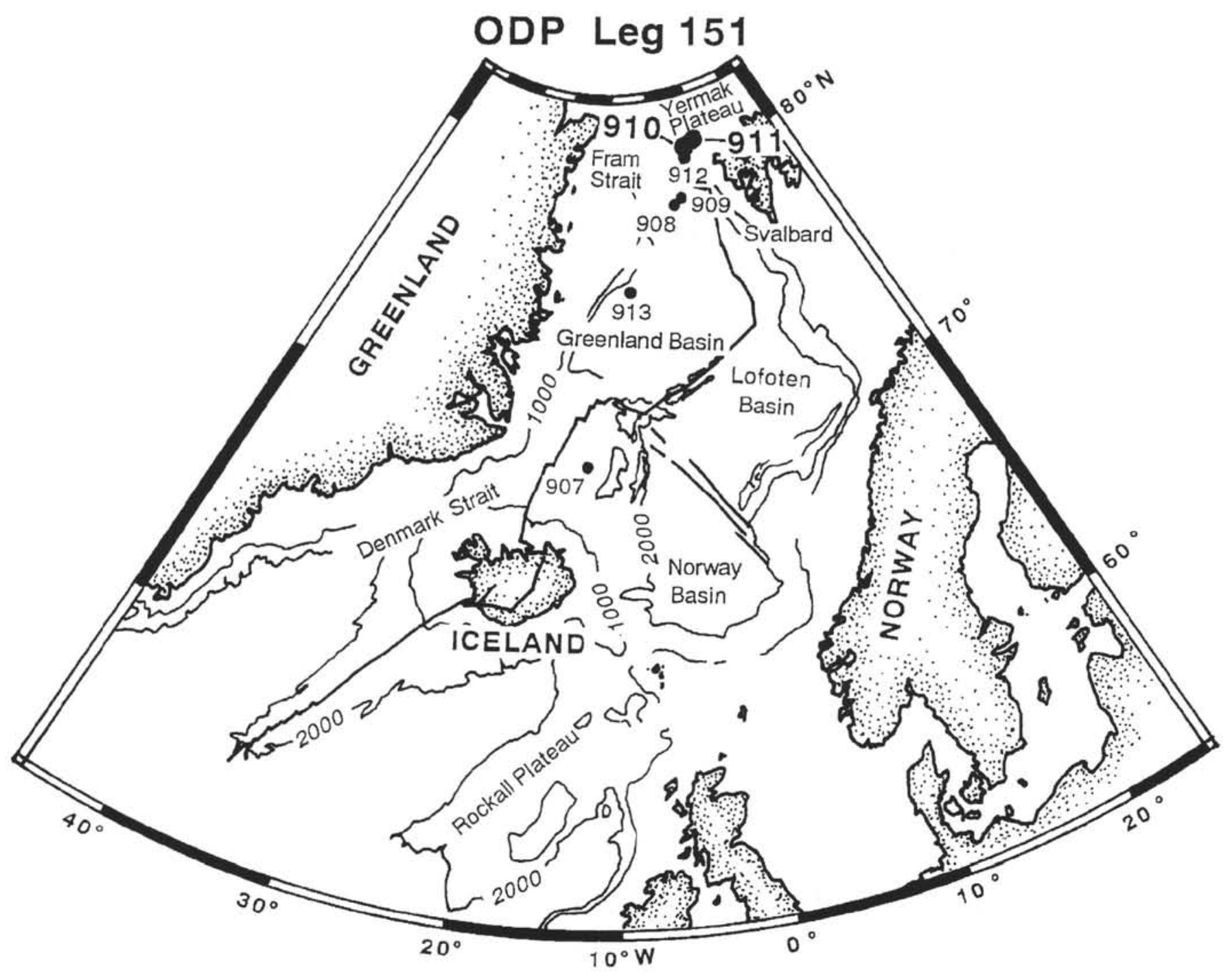

Figure 1. Location map of Sites 910 and 911.

Table 1. Location of Leg 151 sites studied.

\begin{tabular}{lccc}
\hline Hole & Latitude & Longitude & $\begin{array}{c}\text { Water } \\
\text { depth }(\mathrm{m})\end{array}$ \\
\hline $910 \mathrm{~A}$ & $80^{\circ} 15.882^{\prime} \mathrm{N}$ & $06^{\circ} 35.405^{\prime} \mathrm{E}$ & 556.38 \\
$910 \mathrm{C}$ & $80^{\circ} 15.896^{\prime} \mathrm{N}$ & $06^{\circ} 35.430^{\prime} \mathrm{E}$ & 556.38 \\
$911 \mathrm{~A}$ & $80^{\circ} 28.466^{\prime} \mathrm{N}$ & $08^{\circ} 13.640^{\prime} \mathrm{E}$ & 901.58
\end{tabular}

netic polarity of Leg 94 holes (Clement and Robinson, 1987), and new magnetochronology by Cande and Kent (1992). Figure 2 shows the revised ages of these calcareous nannofossil datums. Based on these results, we describe and discuss the Pliocene to Quaternary calcareous nannofossil stratigraphy of the Arctic Ocean in the following section.

\section{LATEST PLIOCENE TO QUATERNARY CALCAREOUS NANNOFOSSIL BIOSTRATIGRAPHY OF HOLES 910A, 910C, AND 911A}

Holes 910A and 910C

Site 910 is located at $556 \mathrm{~m}$ below sea level (mbsl) on the central inner Yermak Plateau in the Arctic Ocean (Fig. 1). Four holes (Holes A, B , C, D) were drilled at this site; two (Holes 910A and 910C) were studied for calcareous nannofossil biostratigraphy.

The core recovery of this site was poor except for the uppermost sequences of Hole 910A. Ninety samples were studied for calcareous nannofossil biostratigraphy; calcareous nannofossils were found in 65 of the 90 samples (Table 2; Fig. 3). The preservation of calcareous 
Table 2. Distribution of calcareous nannofossils in Holes 910A and 910C.

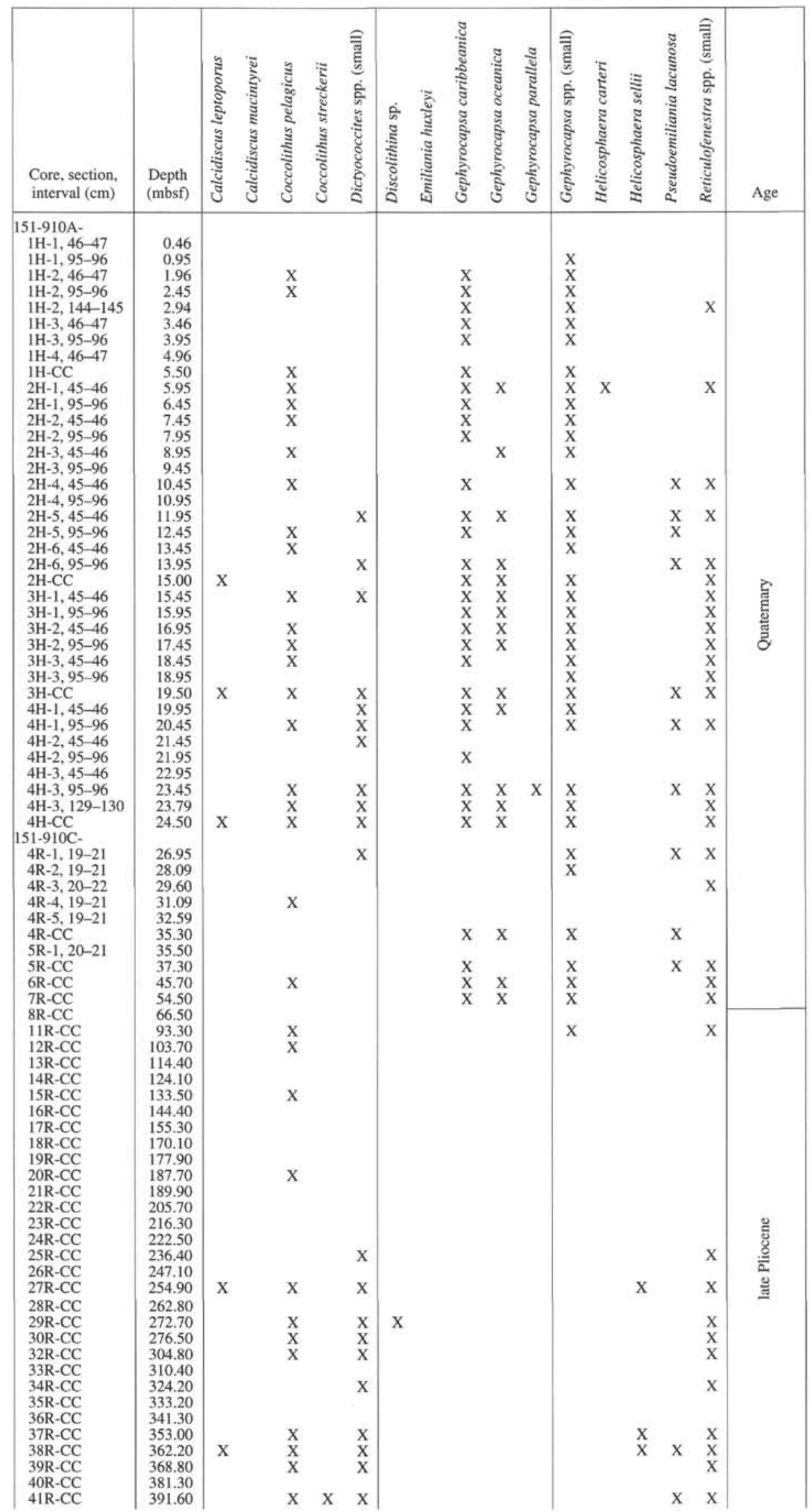


Table 2 (continued).

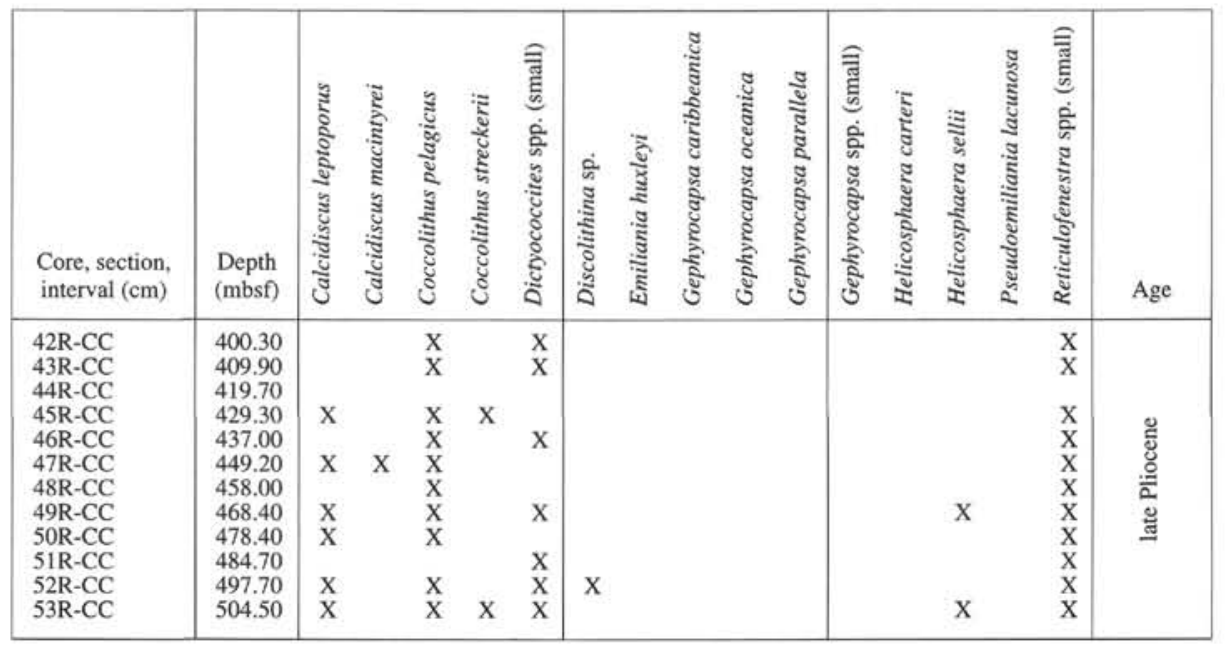

Note: $\mathrm{X}=$ present.

Figure 2. Calcareous nannofossil datums and the relation to magnetostratigraphy $(\mathrm{J}=$ Jaramillo Event; $\mathrm{CM}$ $=$ Cobb Mountain Event $; \mathrm{O}=$ Olduvai Event $)$.

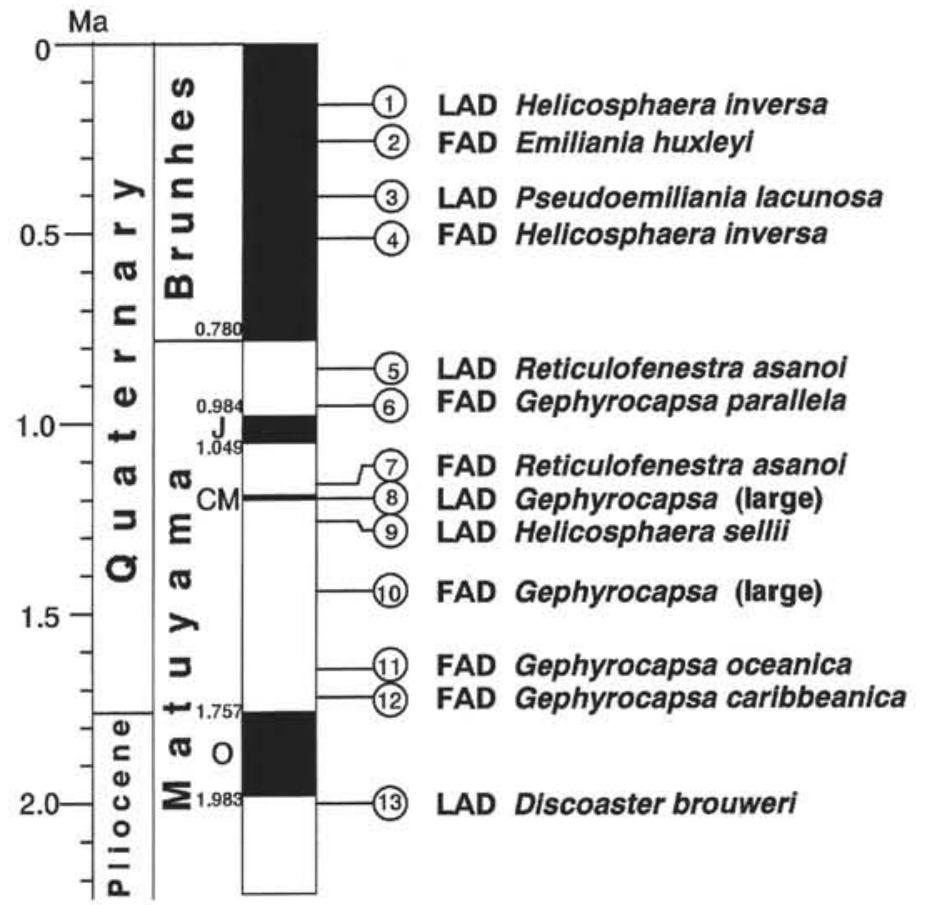

Age (Ma) 0.16 0.25 0.41 0.51 nannofossil specimens is moderate to good; however, the total number of specimens in a slide is less than 60 in most samples.

Emiliania huxleyi, which defines NN21 zone of Martini (1971), is not found in Hole 910A. This may result from barren samples in the uppermost sequence of Hole 910A. Samples 151-910A-1H-2, 46-47 $\mathrm{cm}$, to 151-910A-2H-3, 45-46 cm, contain Gephyrocapsa caribbeanica, G. oceanica, and Coccolithus pelagicus without both Emiliania huxleyi and Pseudoemiliania lacunosa. P. lacunosa, the last appearance of which defines the NN20/NN19 boundary and datum 3 of Sato et al. (1991), occurs in and below Sample 151-910A-2H-4, 45$46 \mathrm{~cm}$. Therefore, datum 3 and the NN19/NN20 boundary is placed between Sample 151-910A-2H-3, 45-46 cm, and 151-910A-2H-4, $45-46 \mathrm{~cm}$. The lowest occurrences of Gephyrocapsa caribbeanica and $G$. oceanica, both index species of the Quaternary, are found between Samples 151-910C-7R-CC and 151-910C-8R-CC. Therefore, the Pliocene/Pleistocene boundary and datums 11 and 12 are placed in this horizon (Fig. 3). Gephyrocapsa parallela, Reticulofenestra asanoi, Gephyrocapsa spp. (large), and Helicosphaera sellii, which define datums 5, 6, 7, 8, 9, and 10 of the Quaternary, are very rare to absent throughout the Quaternary section.

Below the Pliocene/Pleistocene boundary down to Sample 151910C-24R-CC, the abundance of nannofossils is rare (less than 60 specimens in a slide) to barren. Only one species, Coccolithus pelagicus, occurs sporadically in this interval. On the other hand, a remarkable nannofossil event is found in Samples 151-910C-24R-CC to 151-910C-25R-CC. The calcareous nannofossil assemblage below this horizon abruptly changes to higher species diversity and to abundant occurrences of both Reticulofenestra spp. (small) and Dictyococcites spp. (small). This highly diverse assemblage occurs down to Sample 151-910C-53R-CC. Pseudoemiliania lacunosa and Helicosphaera sellii, both of which occur in the latest early Pliocene to Quaternary in the North Atlantic (Takayama and Sato, 1987), are also 


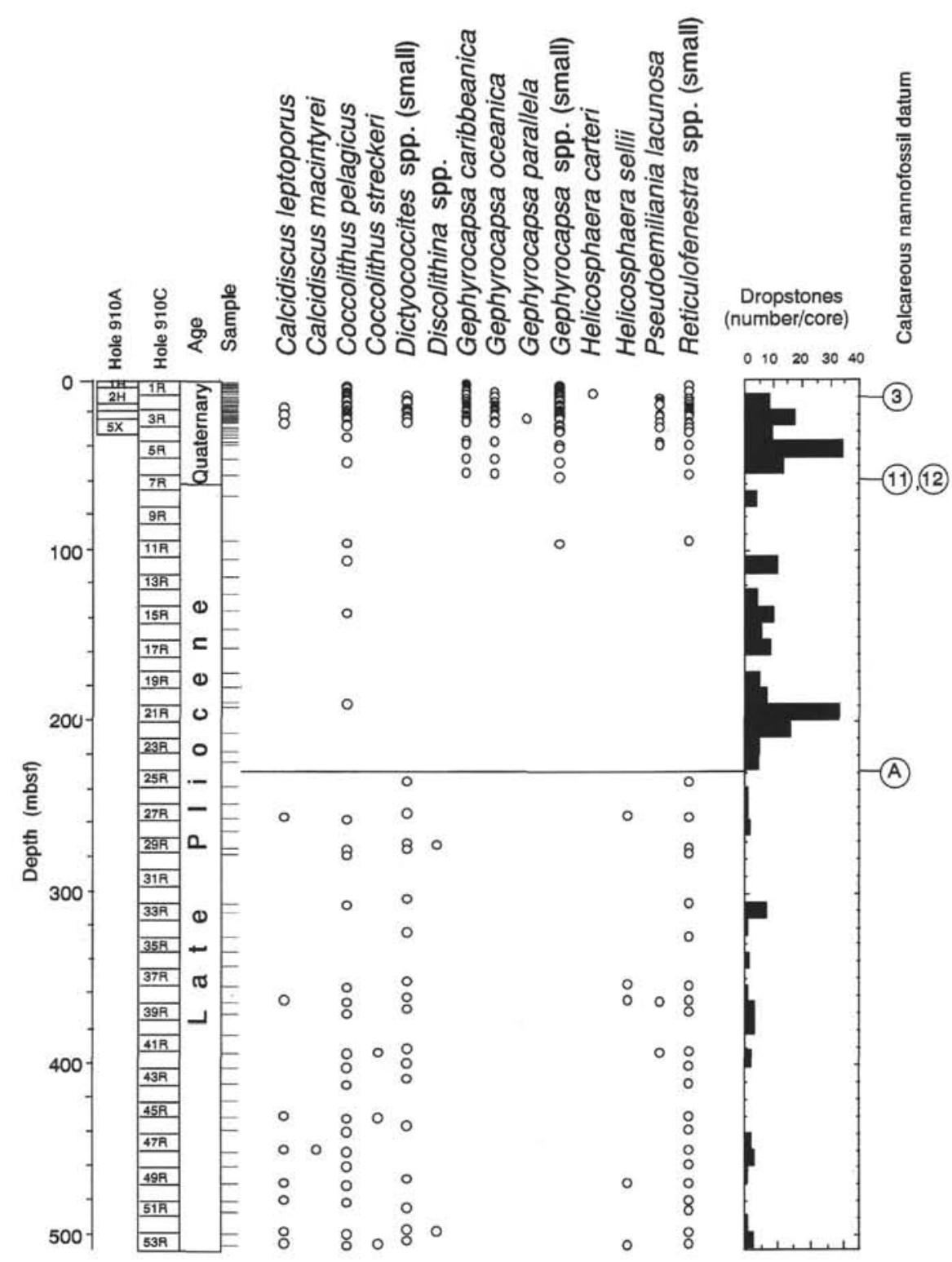

Figure 3. Stratigraphic distribution of calcareous nannofossil species in Holes 910A and 910C (calcareous nannofossil datums: Sato et al., 1991).

found throughout this interval. On the basis of the absence of early Pliocene marker species such as Reticulofenestra pseudoumbilica and Sphenolithus abies and of the presence of both species mentioned above, Samples 151-910C-25R-CC to 151-910C-53R-CC (bottom sample) may be assigned to the late Pliocene.

\section{Hole 911A}

Site 911 is located in the southern part of the Yermak Plateau ( $901.58 \mathrm{mbsl})$ at a moderate distance northeast of Site 910 in the Arctic Ocean (Fig. 1; Table 1).

A total of 606 samples from Hole 911A was studied for calcareous nannofossil biostratigraphy. Although most of the sample sequence of Hole 911A is barren of calcareous nannofossils, 81 of 606 samples contained nannofossil specimens. The abundance of samples wherein calcareous nannofossils occurred was rare to common, or over 200 calcareous nannofossil specimens per slide. Preservation of nannofossil specimens in this hole is moderate to good, and the Qua- ternary marker species of Martini's zonation (1971) and of datum planes in Sato et al. (1991) are found. Eleven genera and 21 species (including "sp.") were recognized, excepting the reworked specimens from the Paleogene to Cretaceous (Table 3; Fig. 4).

Emiliania huxleyi, the marker species of zone NN21 of Martini (1971), occurs from Sample 151-911A-1H-1, 19-20 cm, to Sample 151-911 A-1H-2, 70-71 cm. Therefore, datum 2 (first appearance datum [FAD] E. huxleyi) is placed between Samples 151-911A-1H-2, 70-71 cm, and 911A-1H-CC. Samples from 151-911A-1H-CC to 151-911A-2H-6, 19-21 cm, which are characterized by the absence of both Emiliania huxleyi and Pseudoemiliania lacunosa, are correlated with zone NN20 in the late Quaternary. Pseudoemiliania lacun$o s a$ is found in and below Sample 151-911A-3H-2, 70-71 cm. On the basis of the occurrence of this species, datum 3 (last appearance datum [LAD] $P$. lacunosa and NN19/NN20 boundary of Martini's zonation) is placed between Samples 151-911A-2H-6, 19-21 cm, and 151-911A-3H-2, 70-71 cm. Samples 151-911A-9H-2, 70-71 cm, and $151-911 \mathrm{~A}-9 \mathrm{H}-5,118-119 \mathrm{~cm}$, are characterized by the occur- 
Table 3. Distribution of calcareous nannofossils in Hole 911A.

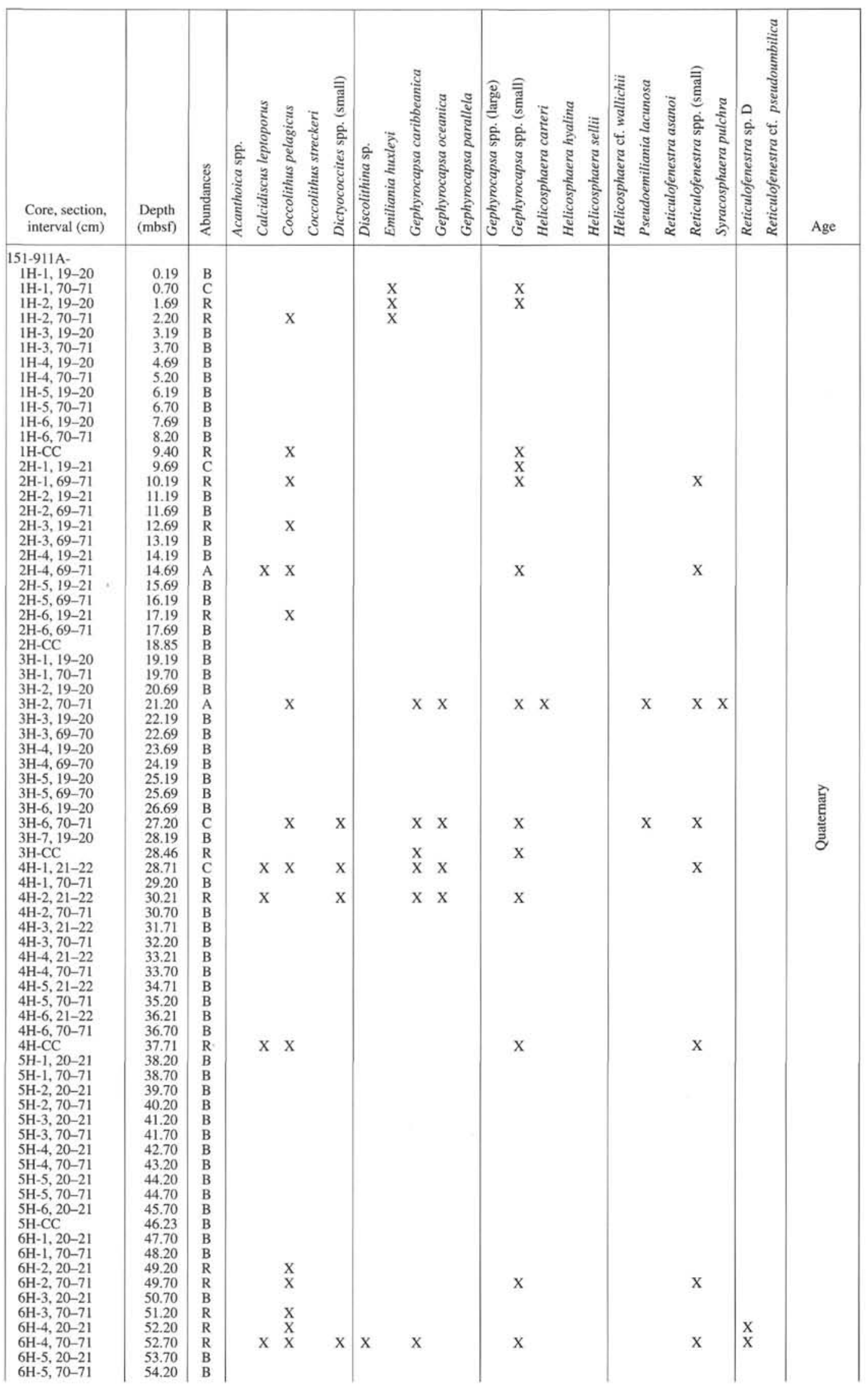


Table 3 (continued).

\begin{tabular}{|c|c|c|c|c|c|c|c|c|c|c|c|c|c|c|}
\hline $\begin{array}{l}\text { Core, section, } \\
\text { interval }(\mathrm{cm})\end{array}$ & $\begin{array}{l}\text { Depth } \\
\text { (mbsf) }\end{array}$ & 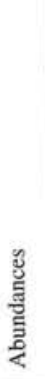 & 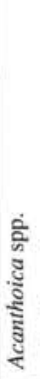 & 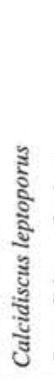 & 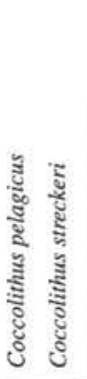 & 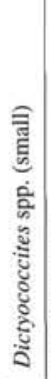 & 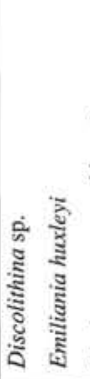 & 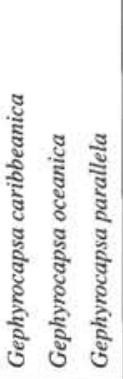 & 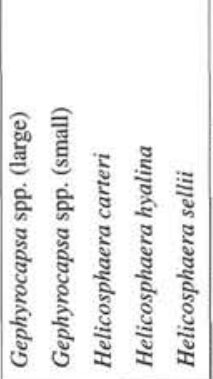 & 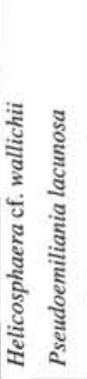 & 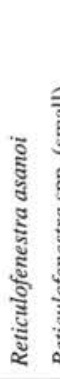 & 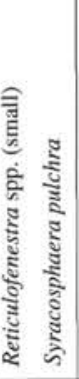 & 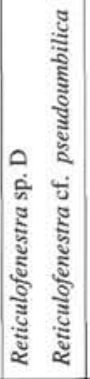 & Age \\
\hline $6 \mathrm{H}-6,20-21$ & 55.20 & B & & & & & & & & & & & & \\
\hline $6 \mathrm{H}-6,70-71$ & 55.70 & $\mathrm{R}$ & & & & & & & & & & & $\mathrm{x}$ & \\
\hline $\begin{array}{l}6 \mathrm{H}-7,20-21 \\
6 \mathrm{H}-\mathrm{CC}\end{array}$ & $\begin{array}{l}56.70 \\
57.27\end{array}$ & $\stackrel{\mathrm{B}}{\mathrm{C}}$ & & & & & & & & & & $\mathrm{X}$ & & \\
\hline $7 \mathrm{H}-1,20-21$ & 57.20 & R & & & $\mathrm{X}$ & $x$ & & $x \quad x \quad x$ & $\mathrm{X}$ & & & $x$ & $\mathrm{X}$ & \\
\hline $7 \mathrm{H}-1,70-71$ & 57.70 & B & & & & & & & & & & & & \\
\hline $7 \mathrm{H}-2,20-21$ & 58.70 & $\mathrm{~B}$ & & & & & & & & & & & & \\
\hline $\begin{array}{l}7 \mathrm{H}-2,70-71 \\
7 \mathrm{H}-3,20-21\end{array}$ & $\begin{array}{l}59.20 \\
60.20\end{array}$ & B & & & & & & & & & & & & \\
\hline $\begin{array}{l}7 \mathrm{H}-3,20-21 \\
7 \mathrm{H}-3,70-71\end{array}$ & $\begin{array}{l}60.20 \\
60.70\end{array}$ & $\begin{array}{l}\mathrm{B} \\
\mathrm{B}\end{array}$ & & & & & & & & & & & & \\
\hline $7 \mathrm{H}-4,20-2 \mathrm{I}$ & 61.70 & B & & & & & & & & & & & & \\
\hline $7 \mathrm{H}-4,70-71$ & 62.20 & B & & & & & & & & & & & & \\
\hline $\begin{array}{l}7 \mathrm{H}-5,20-21 \\
7 \mathrm{H}-5,70-71\end{array}$ & $\begin{array}{l}63.20 \\
63.70\end{array}$ & $\begin{array}{l}\mathrm{B} \\
\mathrm{B}\end{array}$ & & & & & & & & & & & & \\
\hline & $\begin{array}{l}63.70 \\
64.51\end{array}$ & $\begin{array}{l}\mathrm{B} \\
\mathrm{B}\end{array}$ & & & & & & & & & & & & \\
\hline $8 \mathrm{H}-1,20-21$ & 65.40 & B & & & & & & & & & & & & \\
\hline $8 \mathrm{H}-1,70-71$ & 65.90 & B & & & & & & & & & & & & \\
\hline $\begin{array}{l}8 \mathrm{H}-2,20-21 \\
8 \mathrm{H}-2,70-71\end{array}$ & $\begin{array}{l}66.90 \\
67.40\end{array}$ & $\begin{array}{l}\text { B } \\
\text { B }\end{array}$ & & & & & & & & & & & & \\
\hline $8 \mathrm{H}-3,20-2 \mathrm{i}$ & 68.40 & B & & & & & & & & & & & & \\
\hline $\begin{array}{l}8 \mathrm{H}-3,70-71 \\
8 \mathrm{H}-4,20-21\end{array}$ & $\begin{array}{l}68.90 \\
69.90\end{array}$ & $\begin{array}{l}\text { B } \\
\text { B }\end{array}$ & & & & & & & & & & & & \\
\hline $8 \mathrm{H}-4,69-70$ & 70.39 & C & & & $\mathrm{x}$ & & & $\mathrm{x}$ & $\mathrm{X}$ & & & $\mathrm{x}$ & $\mathrm{x}$ & \\
\hline $8 \mathrm{H}-5,20-21$ & 71.40 & B & & & & & & & & & & & & \\
\hline $8 \mathrm{H}-5,69-70$ & 71.89 & $\mathrm{R}$ & & & & & & $\mathrm{x}$ & $\mathrm{x}$ & & & $\mathrm{x}$ & & \\
\hline $8 \mathrm{H}-6,20-21$ & 72.90 & B & & & & & & & & & & & & \\
\hline $\begin{array}{l}8 \mathrm{H}-6,70-71 \\
8 \mathrm{H}-7,20-21\end{array}$ & 73.40 & $\begin{array}{l}\text { B } \\
\text { B }\end{array}$ & & & & & & & & & & & & \\
\hline $\begin{array}{l}8 \mathrm{H}-7,20-2 \mathrm{I} \\
8 \mathrm{H}-\mathrm{CC}\end{array}$ & $\begin{array}{l}74.40 \\
75.13\end{array}$ & $\stackrel{\mathrm{B}}{\mathrm{B}}$ & & & & & & & & & & & & \\
\hline $9 \mathrm{H}-1,21-22$ & 74.91 & B & & & & & & & & & & & & \\
\hline $9 \mathrm{H}-2,21-22$ & 75.51 & B & & & & & & & & & & & & \\
\hline $\begin{array}{l}9 \mathrm{H}-2,70-71 \\
9 \mathrm{H}-3,21-22\end{array}$ & $\begin{array}{l}76.00 \\
7701\end{array}$ & $\begin{array}{l}\mathrm{C} \\
\mathrm{B}\end{array}$ & & $\mathrm{X}$ & $\mathrm{X}$ & $\mathrm{x}$ & & $\mathrm{X}$ & $\mathrm{X}$ & X & $x$ & $x$ & $\mathrm{X}$ & \\
\hline $9 \mathrm{H}-3,70-71$ & & B & & & & & & & & & & & & \\
\hline $9 \mathrm{H}-4,21-22$ & 78.51 & B & & & & & & & & & & & & \\
\hline $\begin{array}{l}9 \mathrm{H}-4,70-71 \\
9 \mathrm{H}-5,21-22\end{array}$ & $\begin{array}{l}79.00 \\
80.01\end{array}$ & $\begin{array}{l}\mathrm{B} \\
\mathrm{R}\end{array}$ & & & & & & & & & & $\mathrm{X}$ & & \\
\hline $9 \mathrm{H}-5,70-71$ & 80.50 & $\mathrm{R}$ & & & $\mathrm{x}$ & & & & $x$ & $\mathrm{X}$ & & & & 宣 \\
\hline $9 \mathrm{H}-5,118-119$ & 80.98 & A & & $\mathrm{x}$ & $\mathrm{x}$ & $\mathrm{x}$ & & & $\mathrm{x}$ & $\mathrm{x}$ & $\mathrm{X}$ & $\mathrm{x}$ & & E् \\
\hline $\begin{array}{l}9 \mathrm{H}-6,21-22 \\
9 \mathrm{H}-6,70-71\end{array}$ & $\begin{array}{l}81.51 \\
82.00\end{array}$ & $\begin{array}{l}\text { B } \\
\text { B }\end{array}$ & & & & & & & & & & & & 爱 \\
\hline $9 \mathrm{H}-7,21-22$ & 83.01 & B & & & & & & & & & & & & \\
\hline $9 \mathrm{H}-7,70-71$ & 83.50 & B & & & & & & & & & & & & \\
\hline $9 \mathrm{H}-\mathrm{CC}$ & 84.00 & $\begin{array}{l}\text { B } \\
\text { B }\end{array}$ & & & & & & & & & & & & \\
\hline $\begin{array}{l}10 \mathrm{H}-1,20-21 \\
10 \mathrm{H}-1,71-72\end{array}$ & $\begin{array}{l}84.40 \\
84.91\end{array}$ & $\begin{array}{l}\text { B } \\
\text { B }\end{array}$ & & & & & & & & & & & & \\
\hline $10 \mathrm{H}-2,20-21$ & 85.90 & B & & & & & & & & & & & & \\
\hline $10 \mathrm{H}-2.71-73$ & 86.41 & B & & & & & & & & & & & & \\
\hline $10 \mathrm{H}-3,20-21$ & $\begin{array}{l}87.40 \\
8701\end{array}$ & B & & & & & & & & & & & & \\
\hline $\begin{array}{l}10 \mathrm{H}-3,71-73 \\
10 \mathrm{H}-4,20-21\end{array}$ & $\begin{array}{l}87.91 \\
88.90\end{array}$ & $\begin{array}{l}\text { B } \\
\text { B }\end{array}$ & & & & & & & & & & & & \\
\hline $10 \mathrm{H}-4,70-71$ & 89.40 & B & & & & & & & & & & & & \\
\hline $10 \mathrm{H}-5,20-21$ & 90.40 & B & & & & & & & & & & & & \\
\hline $10 \mathrm{H}-5,70-71$ & 90.90 & B & & & & & & & & & & & & \\
\hline $\begin{array}{l}10 \mathrm{H}-6,20-21 \\
10 \mathrm{H}-6,69-70\end{array}$ & $\begin{array}{l}91.90 \\
92.39\end{array}$ & $\begin{array}{l}\text { B } \\
\text { B }\end{array}$ & & & & & & & & & & & & \\
\hline $10 \mathrm{H}-\mathrm{CC}$ & 93.95 & B & & & & & & & & & & & & \\
\hline $11 \mathrm{H}-1,20-21$ & 93.90 & B & & & & & & & & & & & & \\
\hline 1IH-1, 70-71 & 94.40 & B & & & & & & & & & & & & \\
\hline $\begin{array}{l}11 \mathrm{H}-2.20-21 \\
11 \mathrm{H}-2,70-71\end{array}$ & $\begin{array}{l}95.40 \\
95.90\end{array}$ & $\begin{array}{l}\text { B } \\
\text { B }\end{array}$ & & & & & & & & & & & & \\
\hline $11 \mathrm{H}-3,20-21$ & 96.90 & B & & & & & & & & & & & & \\
\hline $11 \mathrm{H}-3,70-71$ & 97.40 & B & & & & & & & & & & & & \\
\hline $11 \mathrm{H}-4,20-21$ & $\begin{array}{r}98.40 \\
-0800\end{array}$ & B & & & & & & & & & & & & \\
\hline $\begin{array}{l}11 \mathrm{H}-4,70-71 \\
11 \mathrm{H}-5,24-25\end{array}$ & $\begin{array}{l}98.90 \\
99.94\end{array}$ & $\begin{array}{l}\text { B } \\
\text { B }\end{array}$ & & & & & & & & & & & & \\
\hline $11 \mathrm{H}-5,70-71$ & 100.40 & B & & & & & & & & & & & & \\
\hline $\begin{array}{l}11 \mathrm{H}-\mathrm{CC} \\
12 \mathrm{H}-1,19-20\end{array}$ & $\begin{array}{l}101.40 \\
102.09\end{array}$ & $\begin{array}{l}\mathrm{R} \\
\mathrm{B}\end{array}$ & & $\mathrm{X}$ & & & & & $\mathrm{X}$ & $\mathrm{X}$ & & $\mathrm{X}$ & & \\
\hline $12 \mathrm{H}-1,70-71$ & $\begin{array}{l}102.09 \\
102.60\end{array}$ & $\begin{array}{l}\mathrm{D} \\
\mathrm{B}\end{array}$ & & & & & & & & & & & & \\
\hline $12 \mathrm{H}-2,19-20$ & 103.59 & B & & & & & & & & & & & & \\
\hline $\begin{array}{l}12 \mathrm{H}-2,70-71 \\
12 \mathrm{H}-3,19-20\end{array}$ & $\begin{array}{l}104.10 \\
105.09\end{array}$ & $\begin{array}{l}\text { B } \\
\text { B }\end{array}$ & & & & & & & & & & & & \\
\hline $12 \mathrm{H}-3,70-71$ & 105.60 & B & & & & & & & & & & & & \\
\hline $12 \mathrm{H}-4,19-20$ & 106.59 & B & & & & & & & & & & & & \\
\hline $\begin{array}{l}12 \mathrm{H}-4,70-71 \\
12 \mathrm{H}-5,19-20\end{array}$ & $\begin{array}{l}107.10 \\
108.09\end{array}$ & $\begin{array}{l}\text { B } \\
\text { B }\end{array}$ & & & & & & & & & & & & \\
\hline $12 \mathrm{H}-5,70-71$ & 108.60 & B & & & & & & & & & & & & \\
\hline
\end{tabular}


Table 3 (continued).

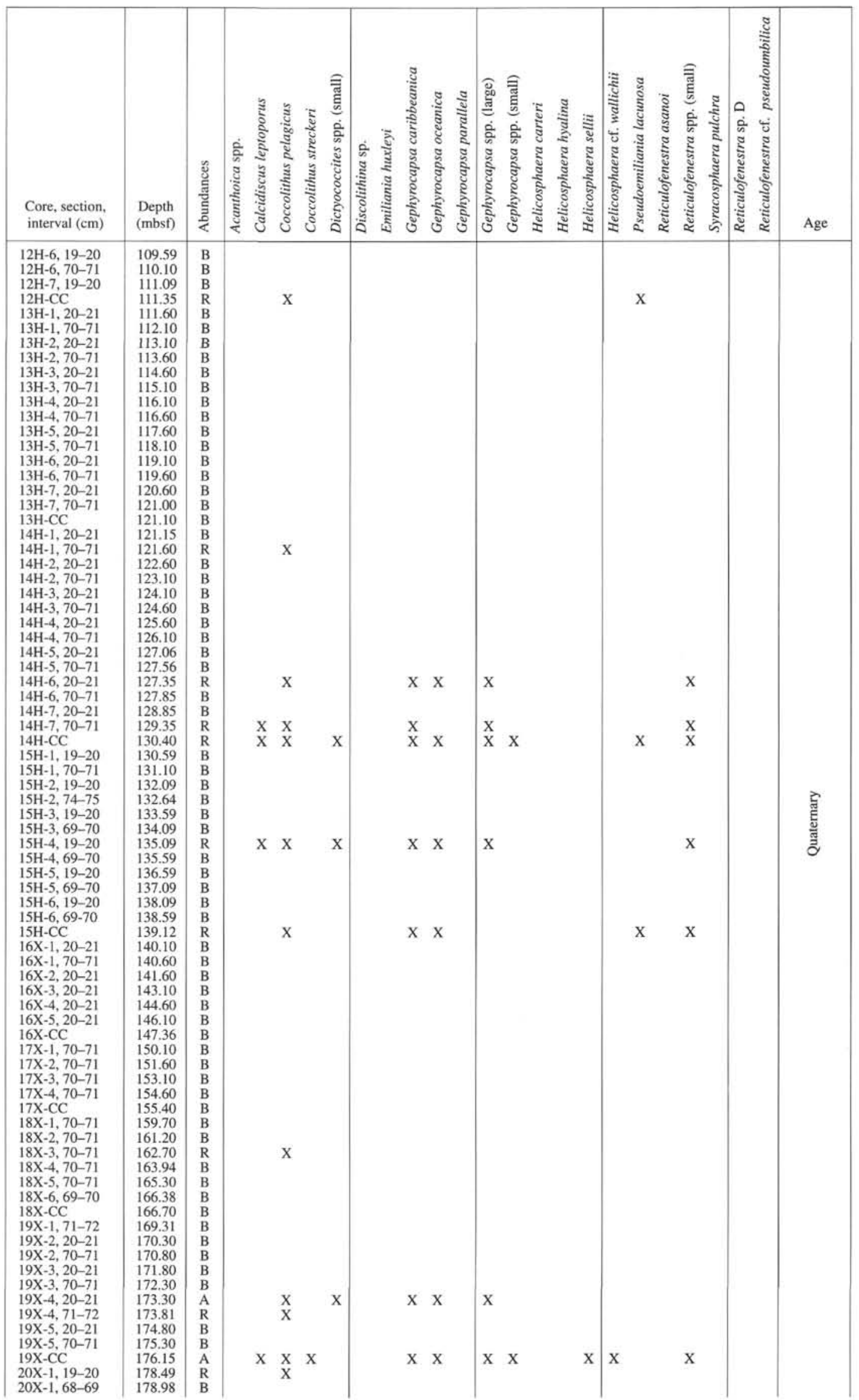


Table 3 (continued).

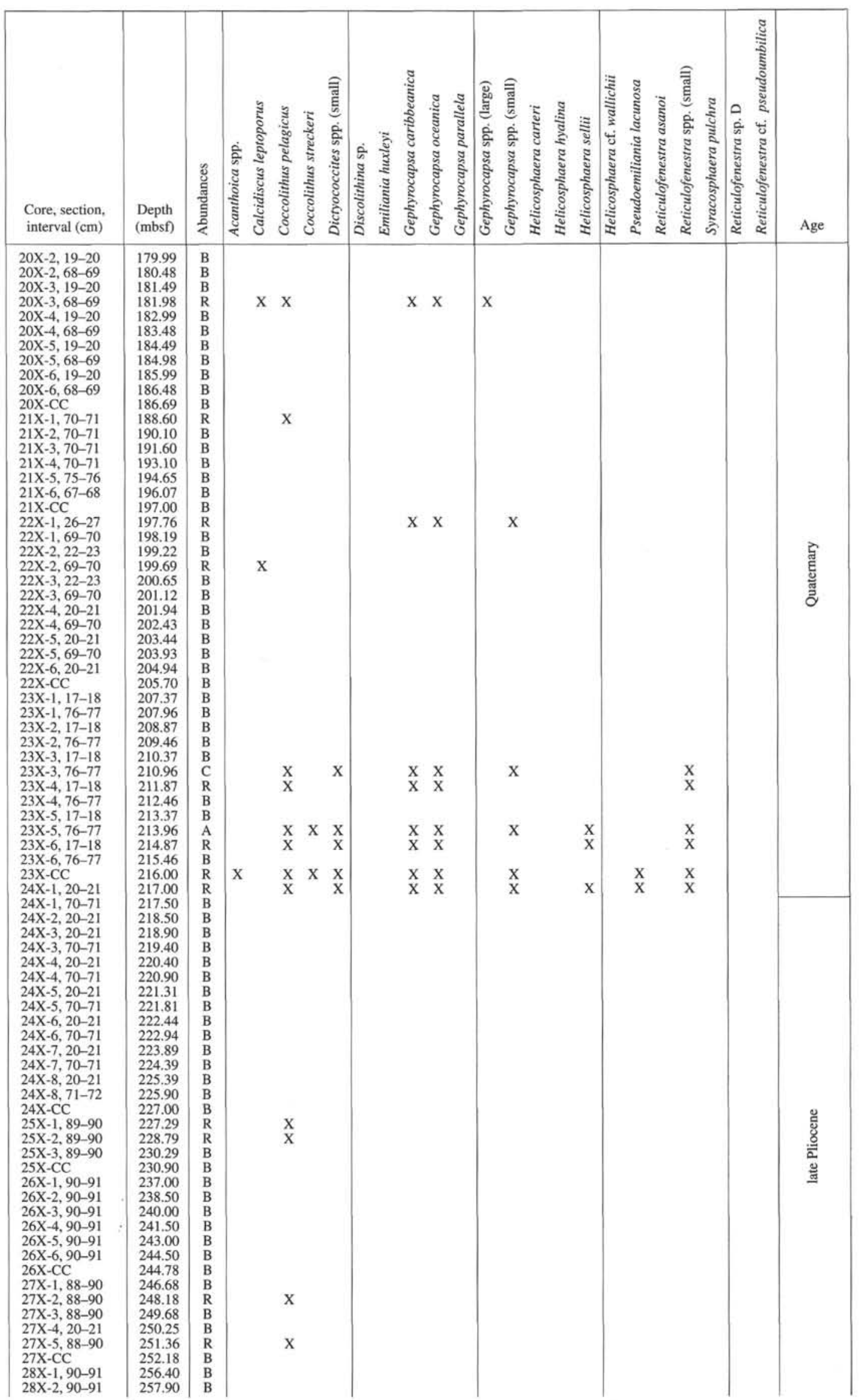


Table 3 (continued).

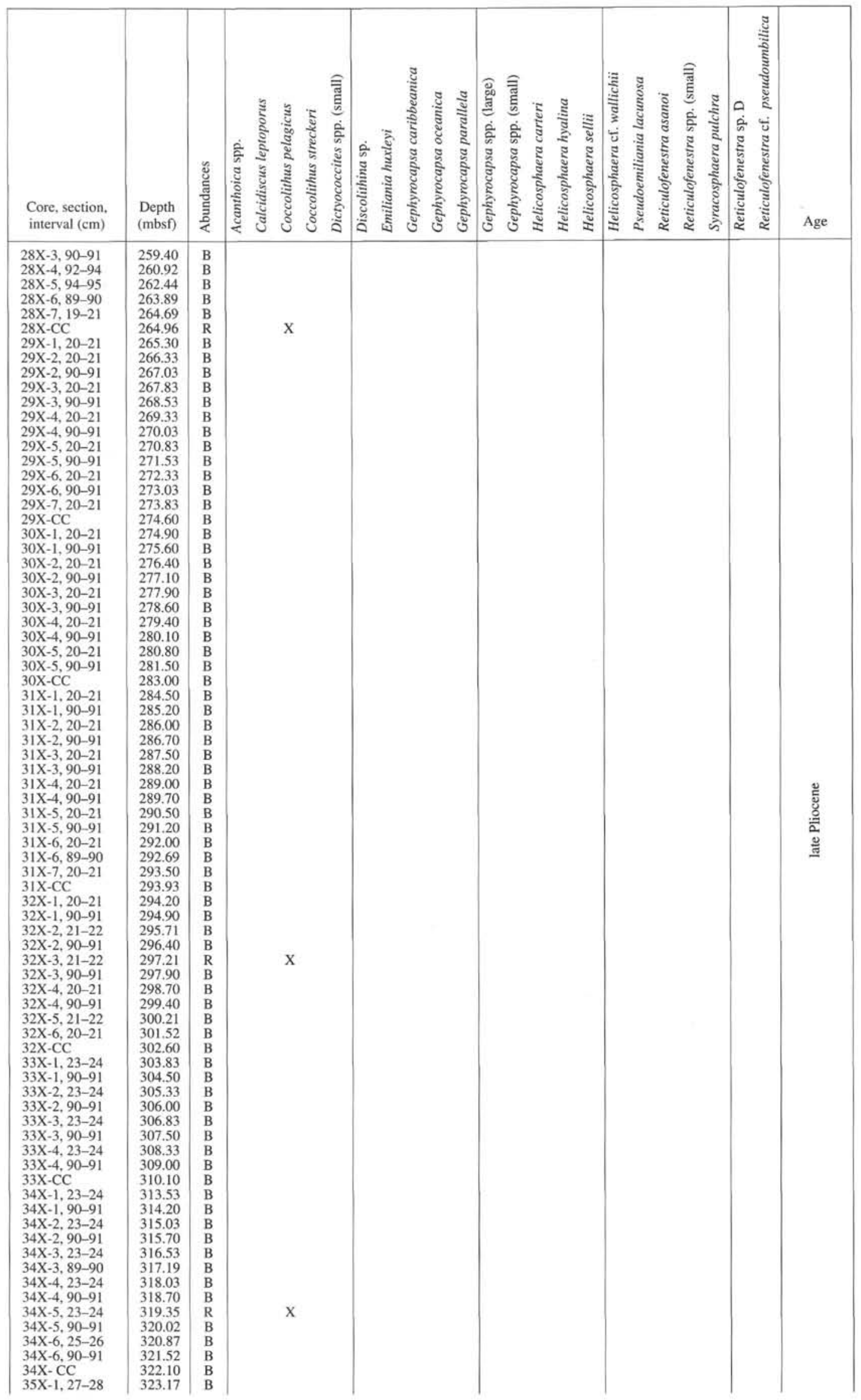


Table 3 (continued).

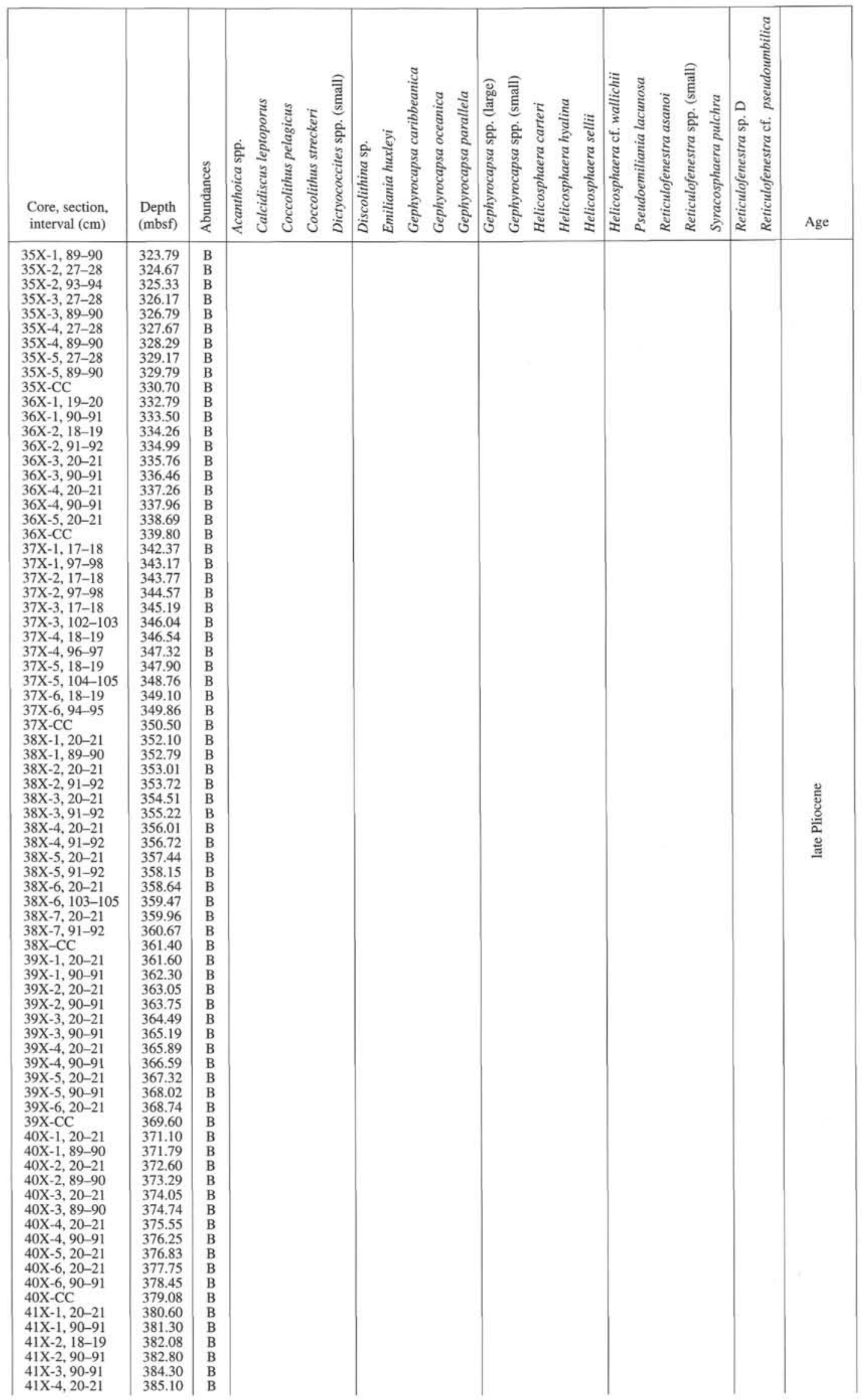


Table 3 (continued).

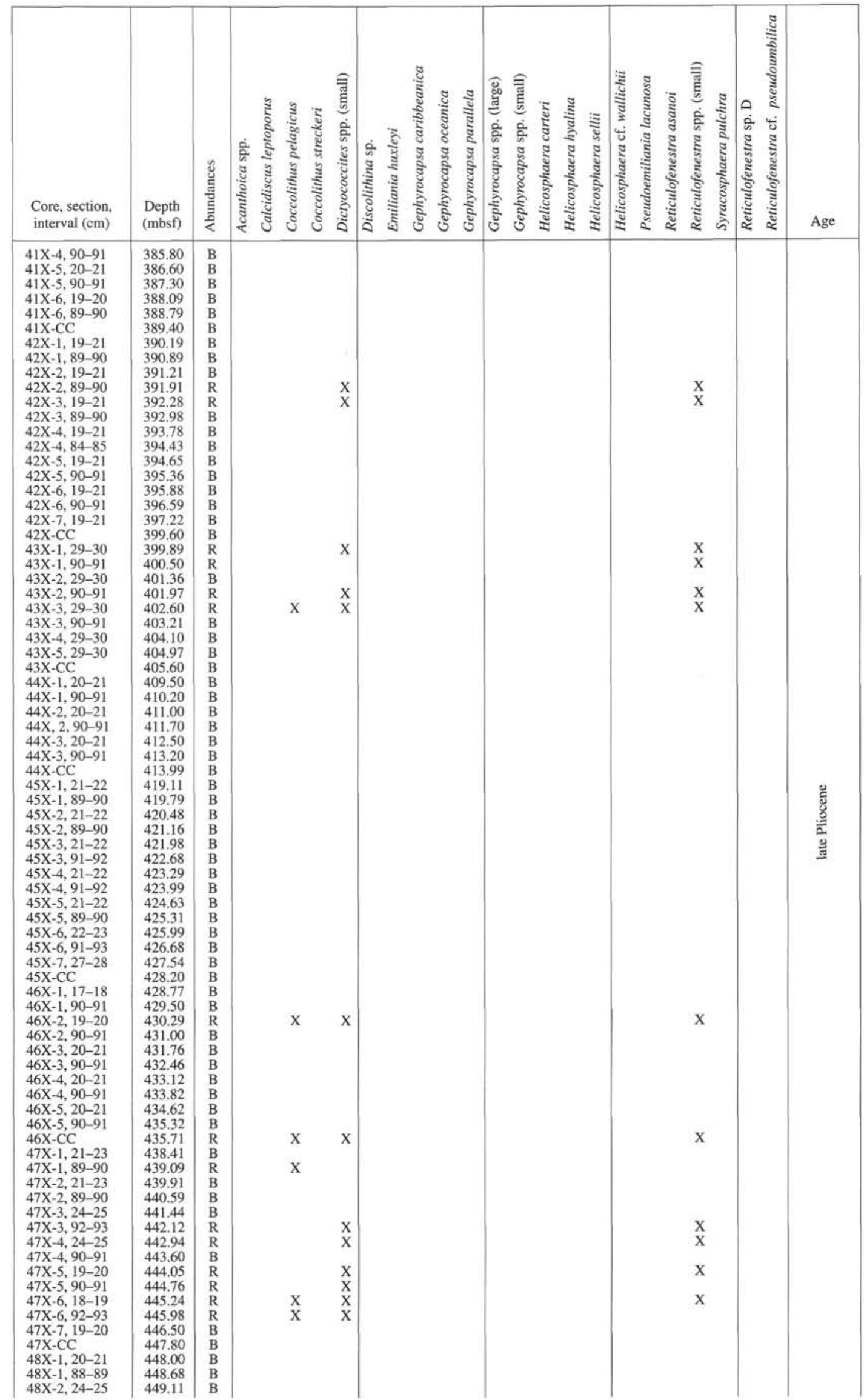


Table 3 (continued).

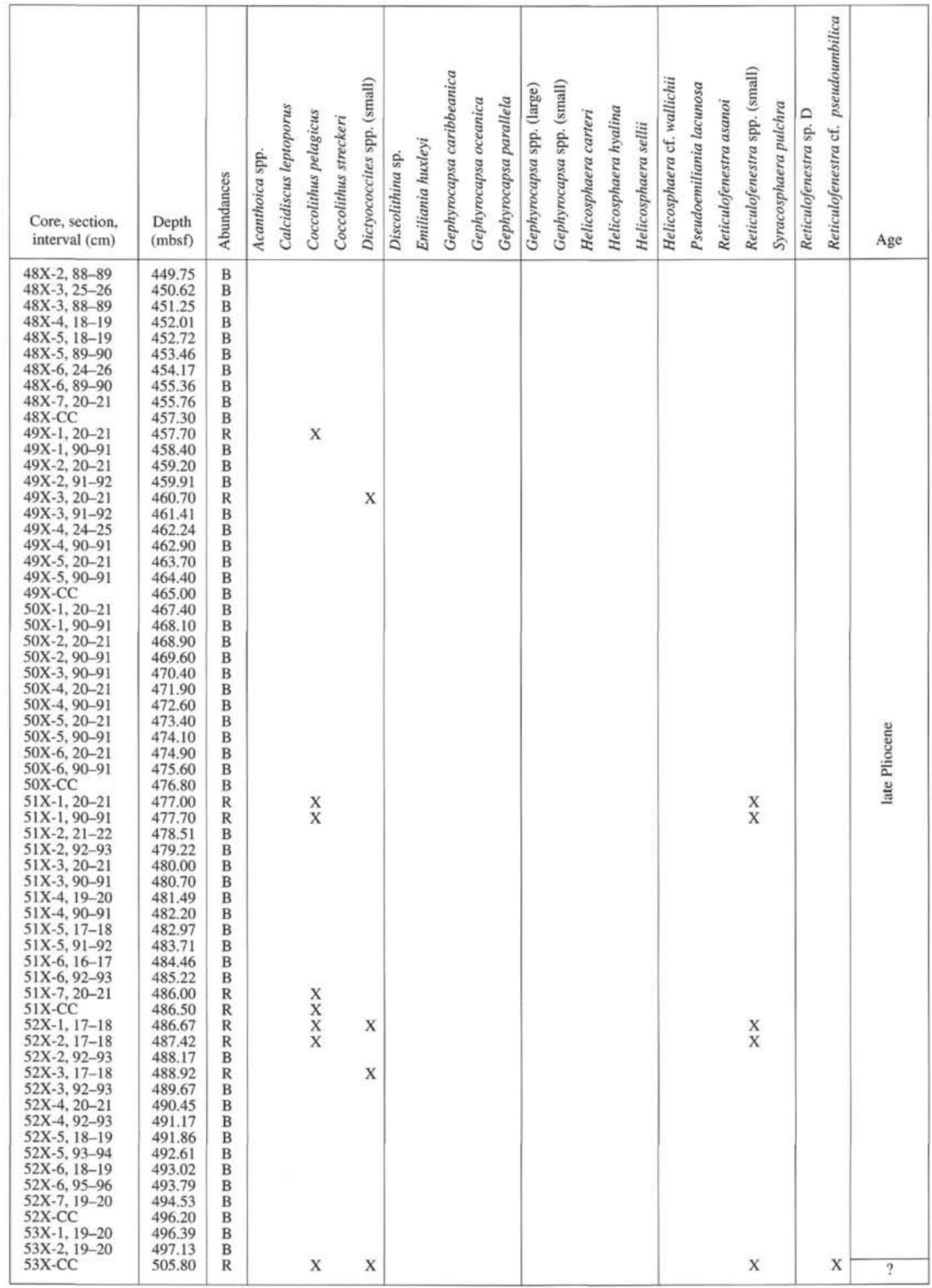

rence of Reticulofenestra asanoi. This indicates that datum 5 (LAD Reticulofenestra asanoi), which is correlated between the Brunhes Normal Epoch and Jaramillo Event in the Matuyama Reversed Epoch (Sato et al., 1991), is placed between Samples 151-911A-8H-5, 69$70 \mathrm{~cm}$, and 151-911A-9H-2, 70-71 cm. Samples 151-911A-9H-6, 21-22 cm, to $151-911 \mathrm{~A}-14 \mathrm{H}-5,70-71 \mathrm{~cm}$, are characterized by the absence of nannofossils or by sporadic and rare occurrences of $\mathrm{Coc}$ - colithus pelagicus. The nannofossil assemblage between Samples $151-911 \mathrm{~A}-14 \mathrm{H}-6,20-21 \mathrm{~cm}$, and 151-911A-20X-3, 68-69 cm, has a relatively higher species diversity. Gephyrocapsa spp. (large), which defines datums 8 and 10 of Sato et al. (1991), occurs in this interval. Helicosphaera sellii, which last appears between datums 8 and 10 (datum 9), occurs sporadically in Samples 151-911A-19X-CC down to $151-911 \mathrm{~A}-24 \mathrm{X}-1,20-21 \mathrm{~cm}$. Therefore, datums 8,9 , and 10 are 
Figure 4. Stratigraphic distribution of calcareous nannofossil species in Hole 911A (calcareous nannofossil datums: Sato et al., 1991).

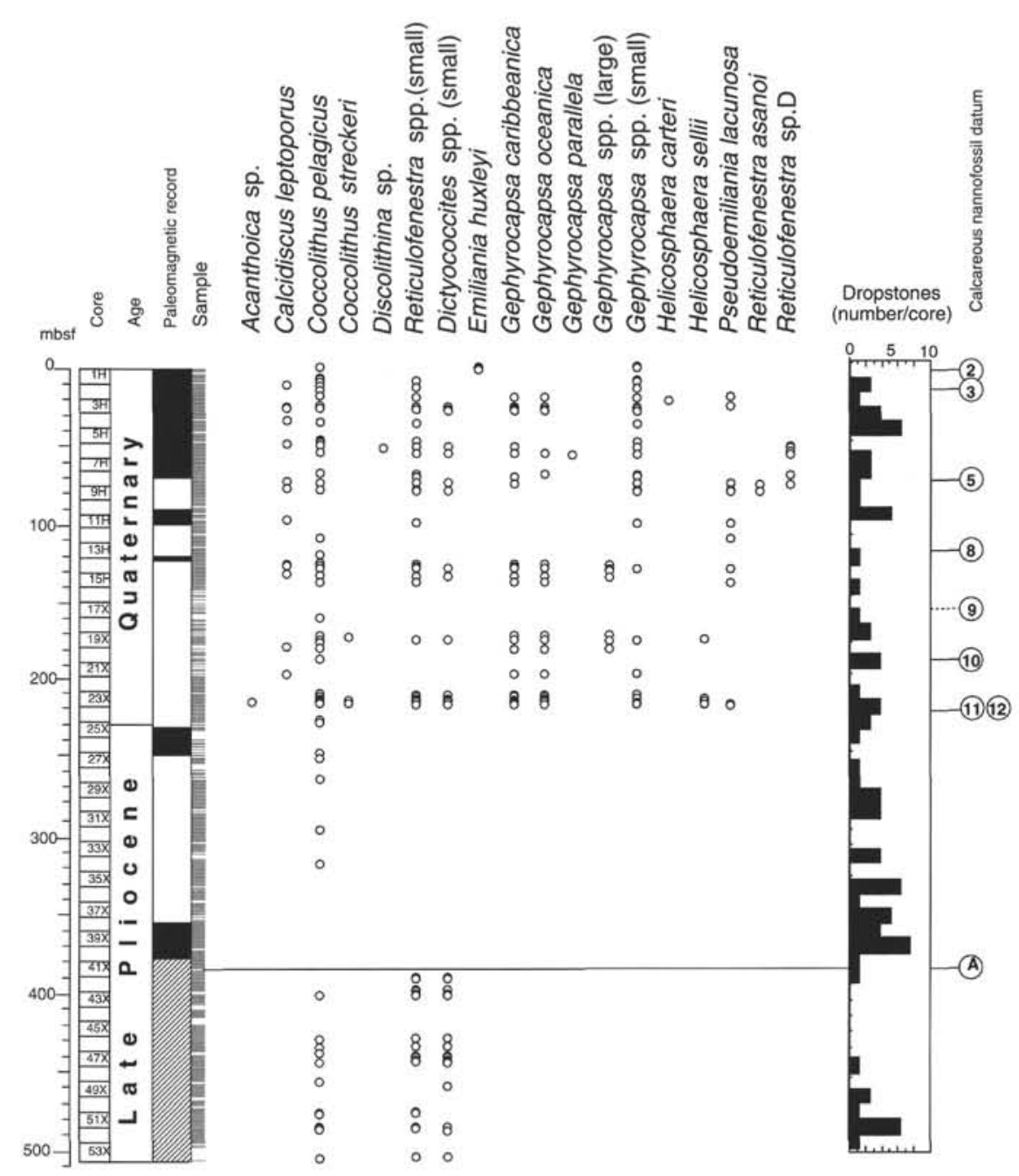

\section{DISCUSSION}

\section{Late Pliocene to Quaternary Calcareous Nannofossil Datum Planes in the Arctic Region}

In the Norwegian-Greenland Sea, the latest Cenozoic calcareous nannofossil biostratigraphy has been studied (Müller, 1976; Donnally, 1989; Gard and Backman, 1990; Henrich and Baumann, 1994). Donnally (1989) studied the calcareous nannofossil assemblages of the Norwegian-Greenland Sea and described the difficulties of applying the standard low-latitude nannofossil zonations in that sea. Finally, she showed three datum planes, the first appearance datum of gephyrocapsids, last appearance datum of Pseudoemiliania lacunosa, and first appearance datum of Emiliania huxleyi, for correlation among sites 642, 643, and 644 in Norwegian-Greenland Sea.

A total of 12 calcareous nannofossil datums, shown in Figure 2, was already recognized in the Quaternary sections of the North Atlantic Ocean, located between $37^{\circ} \mathrm{N}$ and $53^{\circ} \mathrm{N}$ (Takayama and Sato, 1987). These datums were also traced to the Quaternary sequences in Indian Ocean (Leg 117 by Sato et al., 1991), Boso Peninsula in Pacific side of Japan (Sato et al., 1988), and Vrica of Pliocene/Pleistocene boundary stratotype in Italy (Sato et al., 1991; Sato and Takayama, 1992). These facts indicate that these datum planes are useful for the correlation among the Quaternary sequences not only 
Arctic Ocean

(Present study)

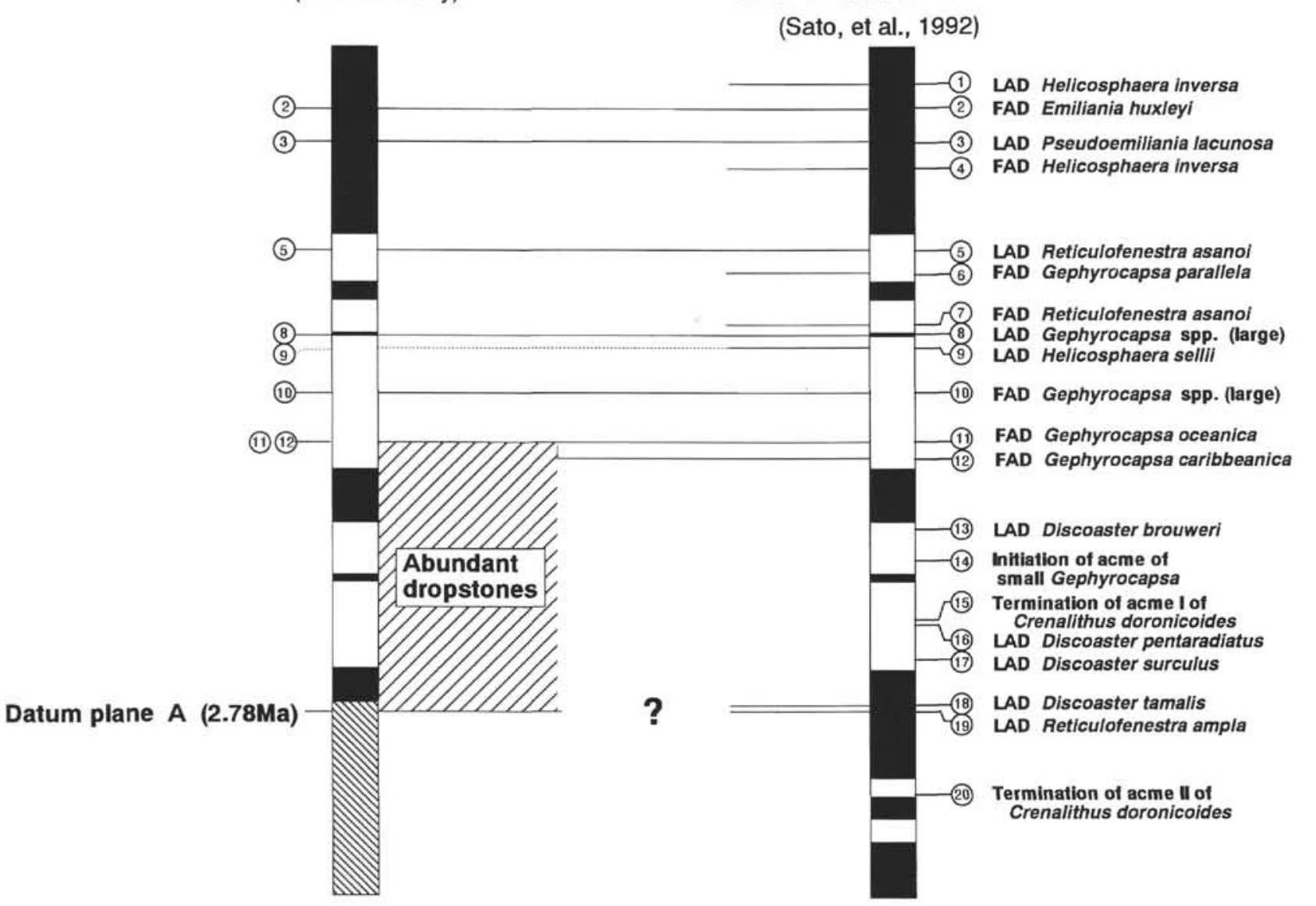

North Atlantic, Indian Ocean, and Pacific Ocean

Age

Figure 5. Calcareous nannofossil datum planes recognized in the Arctic Ocean with reference to nannofossil datums of Sato et al. (1992). in the low-latitude regions but also in middle- to high-latitude regions.

We have described in detail the Quaternary calcareous nannofossil biostratigraphy of three holes drilled in the Arctic region in this study. Although the calcareous nannofossil assemblages found in this area are very low in abundance and have low species diversity, most marker species of the Quaternary datum planes mentioned above occur in the Quaternary section in Hole 911A (Fig. 4). On the basis of detailed paleomagnetic study (Shipboard Scientific Party, 1995b), the relationship between distributions of marker species and the polarity in Hole 911A is shown in Figure 4. Datums 2 and 3 defined by FAD E. huxleyi and LAD P. lacunosa, are found in the late Brunhes Normal Epoch in Hole 911A. Among them, datum 3, which is correlated to oxygen isotope stage 12 (Thierstein et al., 1977; Niitsuma et al., 1991), is also traced to stage 12 (Flower, this volume) in the uppermost Quaternary in Hole 910A. Datum 5, LAD Reticulofenestra asanoi, is placed between the Brunhes Normal Epoch and Jaramillo Event of the Matuyama Reversed Epoch. Datums 8, 9, 10, 11, and 12, defined by the occurrences of Gephyrocapsa spp. (large), Helicosphaera sellii, Gephyrocapsa oceanica, and $G$. caribbeanica are recognized between the Cobb Mountain Event and the Olduvai Event of the Matuyama Reversed Epoch. Datum planes 1, 4, and 6, defined by last and/or first appearance of Helicosphaera inversa and Gephyrocapsa parallela, are not found in this area because of the absence or very rare occurrences of these marker species in the Arctic Ocean. However, most of the Quaternary datum planes are found in Hole
911A, as mentioned above (Fig. 4). Furthermore, the relationship between calcareous nannofossil datum planes and the magnetic polarity recognized in Hole $911 \mathrm{~A}$ is the same as that described by Takayama and Sato (1987) and Sato et al. (1991; Fig. 4). Datum 3, last occurrence of Pseudoemiliania lacunosa, is also found in oxygen isotope stage 12 in a recent study in low latitude regions.

These results indicate that the Quaternary datum planes recognized in the low- to high-latitude regions in the North Atlantic, Pacific, and Indian Oceans, are also applicable to the Arctic Ocean (Figs. $4,5)$. Therefore, we conclude that the Quaternary datum planes described by Takayama and Sato (1987) and Sato et al. (1991) are useful for correlation among Quaternary sequences worldwide.

The Pliocene marker species of Martini's zonation (1971), such as Discoaster brouweri, D. surculus, D. asymmetricus, and D. tamalis, are not found throughout the upper Pliocene sections in Holes 910C and 911 A. This is because these marker species seem to be warm-water species (Haq, 1980). Therefore, this indicates that a detailed correlation among the late Pliocene successions in the high-latitude to Arctic region is difficult based on the discoasters and Pliocene datum planes of Sato et al. (1991; Fig. 5).

However, the remarkable floral change of calcareous nannofossils from Reticulofenestra spp. (small) and Dictyococcites spp. (small) assemblage to Coccolithus pelagicus assemblage was found in the latest Gauss Normal Epoch in Hole 911A (Fig. 4). This event is also recognized in the succession of Hole 910 C (Fig. 3). The utility of this datum in the late Pliocene will be discussed in next section. 


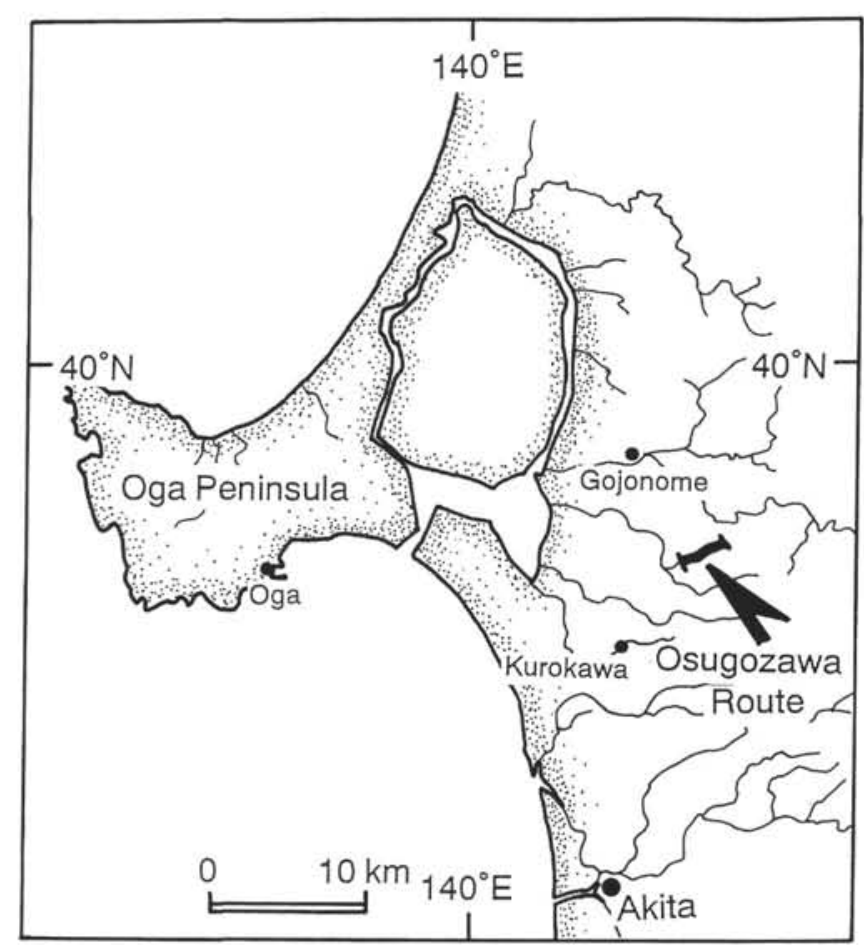

Figure 6. Location map of Osugozawa route in Akita prefecture, northern Japan.

\section{Timing and Development of Polar Cooling}

\section{Late Pliocene Nannofossil Event Recognized in Both Arctic and Japan Sea Side Regions}

A remarkable event characterized by a floral change is found in the Holes 910C and 911A in the late Gauss Normal Epoch in the late Pliocene. The calcareous nannofossils below the event are characterized by moderate species diversity and abundant occurrences of both Reticulofenestra spp. (small) and Dictyococcites spp. (small). Some other species such as Helicosphaera sellii, Pseudoemiliania lacunosa, and Discolithina spp. are also found in this interval in Hole 910C. The assemblage above this event is rare or barren until the Pliocene/Pleistocene boundary. Only Coccolithus pelagicus occurred in this interval (less than 60 specimens) and occupied the assemblage in this sequence.

Similar floral changes are also found in the upper Pliocene sequence in the Osugozawa route in the Akita area, which is located on the Japan Sea side in northern Japan (Fig. 6). The Pliocene Sasaoka and Tentokuji Formations, widely distributed in the Akita area, contain abundant calcareous nannofossils without discoasters, as in the Arctic region. Figure 7 shows the calcareous nannofossil biostratigraphy of the Tentokuji and Sasaoka Formations in the Osugozawa route (with magnetic polarity; Noritomi et al., 1980). The calcareous nannofossils in the Tentokuji to lower Sasaoka Formations are characterized by abundant occurrences of both Reticulofenestra spp. (small) and Dictyococcites spp. (small). Rare numbers of Helicosphaera sellii, Discolithina spp., and Calcidiscus leptoporus are also found in this section. In the upper Sasaoka Formation, the calcareous nannofossil assemblage changes to a dominant occurrence of Coccolithus pelagicus with few specimens of other species in the late Gauss Normal Epoch.

This drastic floral change recognized in the Osugozawa route in Akita, Japan, is correlated with the late Pliocene event found in the
Arctic Ocean, on the basis of the characteristics of nannofossil assemblage and relation to the magnetic polarity (Fig. 8).

Based on these results, we give the name datum A to this event (Figs. 3, 4, 5, 7, and 8), which is defined by the floral change as follows:

Datum A: Floral change from abundant occurrences of both Reticulofenestra spp. (small) and Dictyococcites spp. (small) to barren nannofossil or to Coccolithus pelagicus assemblage. This datum is correlated to the late Gauss Normal Epoch at Hole $911 \mathrm{~A}$ in the Arctic Ocean and the Osugozawa route in Akita prefecture, on the Japan Sea side of Japan. Age is $2.78 \mathrm{Ma}$, based on the relationship between magnetic polarity (the Gauss/Matuyama boundary) and the stratigraphic position of datum $\mathrm{A}$ in Hole 911A.

The relation between datum A and the late Pliocene datum planes of Sato et al. (1991) is not clear because of absence of discoasters. On the basis of stratigraphic position and the age of the datums in the late Pliocene, datum A may be correlated with LAD D. tamalis or LAD R. ampla.

\section{Relationship Between Datum Plane A and the Late Pliocene Glaciation}

The history of the large glaciation in the high northern latitudes has been documented to about $2.5 \mathrm{Ma}$ (Shackleton et al., 1984; Jansen et al., 1988). Jansen et al. (1990) noted that the first large pulse of IRD (ice-rafted debris) appears a little earlier in the Norwegian Sea (2.57Ma) than in the North Atlantic record (2.44Ma). Whitman and Berger (1992) also reported that there was an increase in the volume of the northern hemisphere ice at $2.8 \mathrm{Ma}$ in the glacial and interglacial cycles based on oxygen isotope record.

The calcareous nannofossil assemblages above datum plane A $(2.78 \mathrm{Ma})$ are barren or characterized by the dominant occurrence of Coccolithus pelagicus and by very low species diversity compared with the sequence below this datum. The floral change from a higher species diversity to a Coccolithus pelagicus assemblage indicates the paleoclimatic change from warmer conditions to a cool environment at 2.78 Ma in the late Gauss Normal Epoch, based on the low species diversity and on the characteristic of Coccolithus pelagicus, which lives in cold water in high-latitude regions (Baumann and Matthiessen, 1992; Roth, 1994; Samtleben et al., 1995).

During ODP Leg 151, the stratigraphic distribution of dropstones were also studied in each hole (Shipboard Scientific Party, 1995a, 1995b). Figures 3, 4, and 8 show the relationship between the calcareous nannofossil biostratigraphy and stratigraphic distribution of dropstones with datum planes in each holes. According to these results, a drastic increase of dropstones is found in the horizon just above datum $\mathrm{A}$ in Holes 911 A and 910C. The abundant occurrence of the dropstones continues until latest Pliocene, just below datum 12 (Figs. 5 and 8). This distribution of dropstones indicates that calcareous nannofossil datum $\mathrm{A}$ is strongly related to the increase of ice sheets in the northern hemisphere. These results also support the result of the paleoclimatic analysis, based on calcareous nannofossils that indicate paleoclimatic conditions changed from warm to cool at $2.78 \mathrm{Ma}$ (datum A).

\section{Stepwise Evolution of the Norwegian Current in the Late Pliocene to Quaternary}

Henrich and Baumann (1994) described that glacial/interglacial environmental contrasts are increased step-by-step from $2.6-1.0 \mathrm{Ma}$ to $1.0-0.6 \mathrm{Ma}$, and to $0.6 \mathrm{Ma}$ to present. They also showed that in the paleoceanographic condition of the Norwegian-Greenland Sea, longterm, stable, small ice caps on the surrounding land masses were 


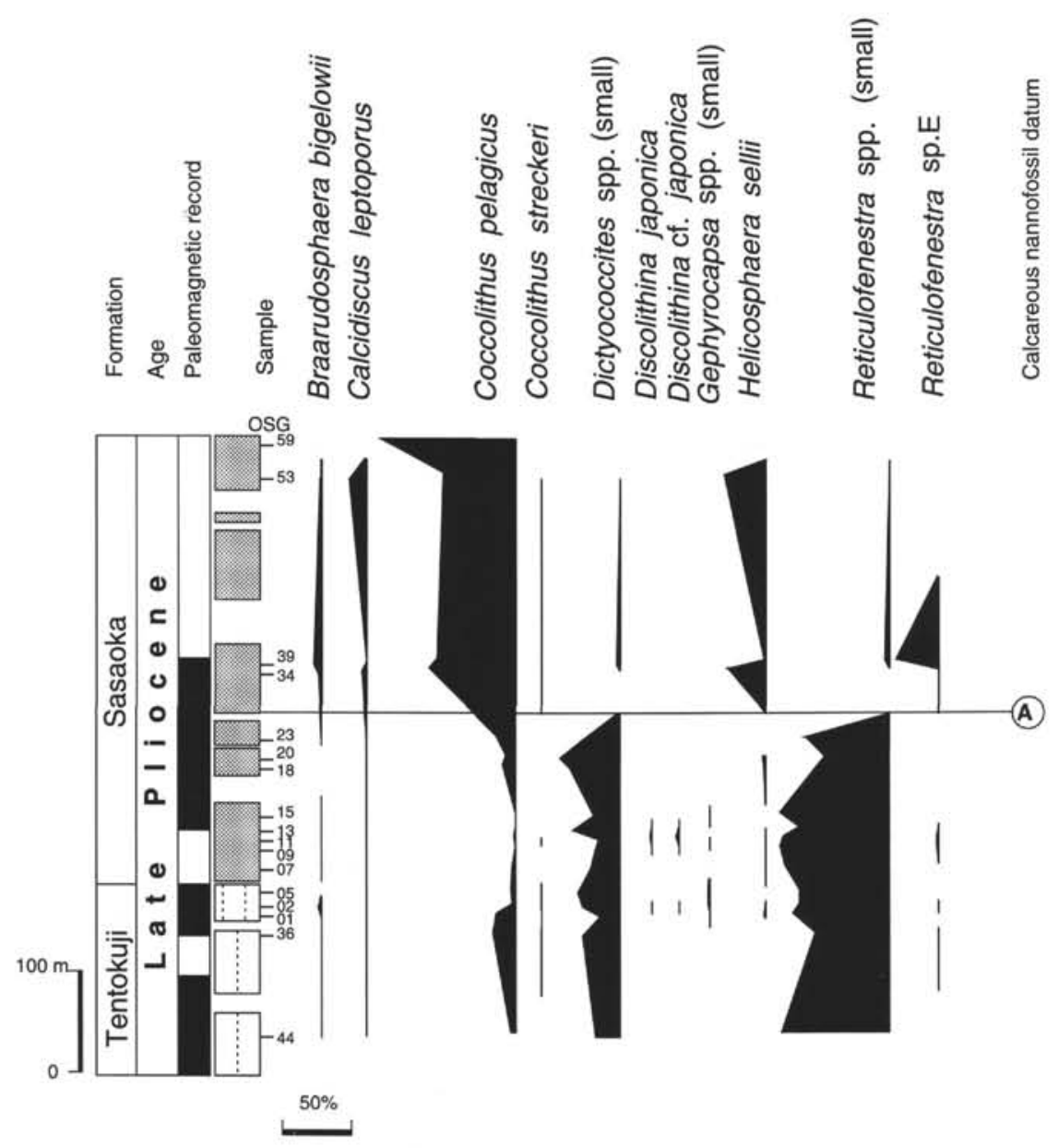

Figure 7. Stratigraphic distribution of calcareous nannofossil species in the Osugozawa route.

widely developed, and the small-scale Atlantic water intrusions penetrated into the Norwegian Sea within a narrow tongue along the eastern margin during 2.60-1.0 Ma.

No calcareous nannofossils occurred in the Pliocene to the lower Quaternary in the holes located in the Iceland Plateau, the eastern Greenland margin, and the western part of the Fram Strait (Sites 907, 908, 909, and 913; Shipboard Scientific Party, 1995a, 1995b). However, calcareous nannofossils occur in the Pliocene to the Quaternary sequence of Holes 910A, 910C, and 911A located near Svalbard. On the basis of the abundance of calcareous nannofossil specimens in the sequence of Holes 910A, 910C, and 911A, the late Pliocene to Quaternary is roughly divided into four intervals:

1. Below datum A (Late Pliocene before $2.78 \mathrm{Ma}$ ): Reticulofenestra spp. (small) assemblage with few other species such as Dictyococcites spp. (small), Pseudoemiliania lacunosa, Calcidiscus leptoporus, and Helicosphaera sellii. The abundance of calcareous nannofossils is rare.

2. Interval between datum A and datum 11 (between $2.78 \mathrm{Ma}$ and 1.7 Ma): no nannofossils or only a few Coccolithus pelagicus specimens are found.

3. Interval between datum 11 and just above the Jaramillo Event (1.7 Ma- 1.0 Ma): abundance of calcareous nannofossils is rare; however, species diversity is high, and the marker species of Sato et al. (1992) are found.

4. Interval between just above the Jaramillo Event and present (about 1.0 Ma-present): the contrast between the presence and absence of calcareous nannofossils becomes greater. Over 200 specimens were sometimes found in smear slides in which specimens reworked from the Paleogene to Cretaceous were also abundant.

These results indicate that the sea ice was widely developed in the central to western part of the Norwegian-Greenland Sea throughout the Late Pliocene to Quaternary. However, the Norwegian Current intrusions sometimes penetrated to the Arctic Ocean through the eastern edge of the Norwegian-Greenland Sea along Svalbard. The strength of this current increased in a stepwise manner at $1.7 \mathrm{Ma}$ and 1.0 Ma after the glaciation at $2.78 \mathrm{Ma}$. Among them, the glacial/interglacial environmental contrasts are increased in the late Quaternary during $1.0 \mathrm{Ma}$ to Holocene, with the result that common to abundant calcareous nannofossil specimens sporadically occurred in the upper Quaternary (Table 3). These results support the stepwise evolution of the Norwegian Current at $1.0 \mathrm{Ma}$ described by Henrich and Baumann (1994).

\section{CONCLUSION}

The calcareous nannofossil biostratigraphy of the Arctic Ocean was studied in detail. Although the abundance and species diversity of the calcareous nannofossil flora was poor, the Quaternary marker species of Takayama and Sato (1987) and Sato et al. (1991) occurred throughout the section. This indicates that the Quaternary datum planes of Takayama and Sato (1987) are applicable to the Arctic Ocean.

The utility of the late Pliocene new datum plane A, defined by the floral change from a Reticulofenestra spp. (small) assemblage to a 


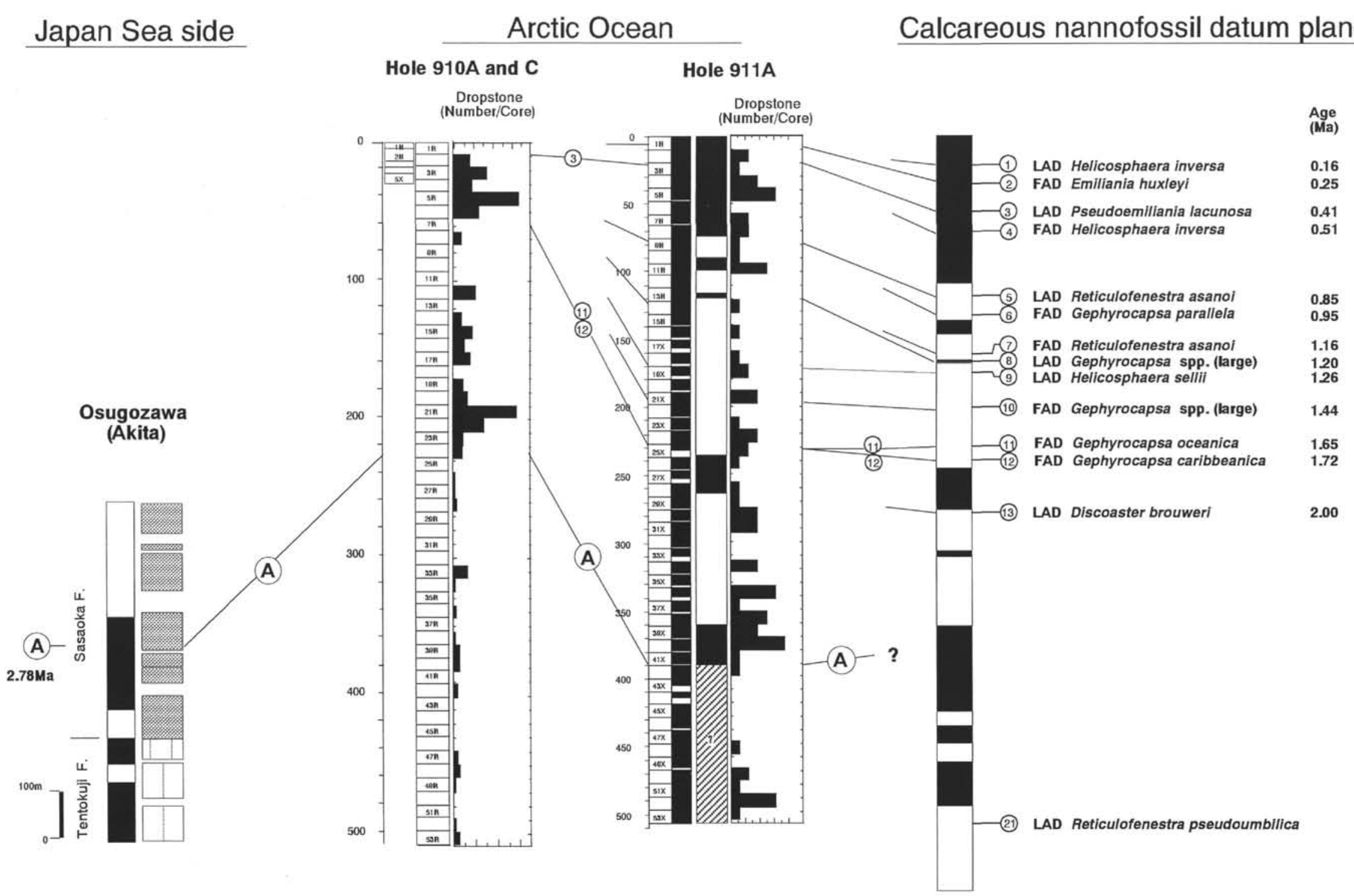

Figure 8. Correlation among Holes 910A, 910C, 911A, and Osugozawa route based on nannofossil datums of Sato et al. (1992) and datum A. 
Coccolithus pelagicus assemblage, is described. This datum plane, placed in the late Gauss Normal Epoch in the successions in both the Japan Sea side of Japan and in the Arctic Ocean, is assigned to the horizon of increasing dropstones in Holes 910C and 911A. These facts indicate that the paleoclimate conditions changed from warm to cool conditions at $2.78 \mathrm{Ma}$ (datum A).

\section{ACKNOWLEDGMENTS}

We are grateful to many of the scientific staff on board the JOIDES Resolution. Deep appreciation is expressed to Dr. John Firth for his help and review of the manuscript. The authors are also deeply indebted to Professors Toshiaki Takayama and Yasumochi Matoba for their helpful advice and comments on the manuscript. We thank Miss Hiroko Abe for assistance in cataloging of samples and preparations.

\section{Floral Reference List}

Eleven genera and 23 species (including "sp.") that were recognized during this investigation are listed below.

\section{Acanthoica spp.}

Calcidiscus leptoporus (Murray and Blackman) Loeblich and Tappan, 1978. Calcidiscus macintyrei (Bukry and Bramlette) Loeblich and Tappan, 1978. Coccolithus pelagicus (Wallich) Schiller, 1930.

Coccolithus streckeri Takayama and Sato, 1987.

Dictyococcites spp. (small).

Discolithina spp.

Emiliania huxleyi (Lohmann) Hay and Mohler, 1967.

Gephyrocapsa caribbeanica Boudreaux and Hay, 1967.

Remarks: This species was identified by characteristic features such as size (larger than $4 \mu \mathrm{m}$ ) and orientation of the diagonal bar (greater than a $45^{\circ}$ angle with short axis). Specimens larger than $6 \mu \mathrm{m}$ were considered Gephyrocapsa spp. (large).

Gephyrocapsa oceanica Kamptner, 1943.

Remarks: This species was identified by characteristic features such as size (larger than $4 \mu \mathrm{m}$ ) and orientation of the diagonal bar (less than a $45^{\circ}$ angle with short axis). Specimens larger than $6 \mu \mathrm{m}$ were considered Gephyrocapsa spp. (large).

Gephyrocapsa parallela Hay and Beaudry, 1973.

Remarks: This species is similar to $G$. oceanica, but differs in orientation of the diagonal bar (nearly $0^{\circ}$ angle with a short axis). This species first appears just above the Jaramillo event and occurs continuously throughout the upper Quaternary sequence in the North Atlantic (Leg 94). However, it is very rare or absent in the Arctic Ocean.

Gephyrocapsa spp. (large).

Remarks: Specimens of $G$. oceanica and $G$. caribbeanica larger than 6 $\mu \mathrm{m}$ are included in $G$. spp. (large).

Gephyrocapsa spp. (small).

Remarks: Gephyrocapsa specimens smaller than $4 \mu \mathrm{m}$ are included in $G$. spp. (small).

Helicosphaera carteri (Wallich) Kamptner, 1954.

Helicosphaera hyalina Gaarder, 1970.

Helicosphaera sellii (Bukry and Bramlette) Jafar and Martini, 1975.

Helicosphaera cf. wallichii (Lohmann) Okada and McIntyre, 1977.

Pseudoemiliania lacunosa (Kamptner) Gartner, 1969.

Reticulofenestra asanoi Sato and Takayama, 1992.

Reticulofenestra sp. D.

Reticulofenestra sp. E.

Reticulofenestra spp. (small).

Reticulofenestra cf. pseudoumbilica (Gartner) Gartner.

Syracosphaera pulchra Lohmann, 1902.

\section{REFERENCES}

Baumann, K.-H., and Matthiessen, J., 1992. Variations in surface water mass conditions in the Norwegian Sea: evidence from Holocene coccolith and dinoflagellate cyst assemblages. Mar. Micropaleontol., 20:129-146.
Cande, S.C., and Kent, D.V., 1992. A new geomagnetic polarity time scale for the Late Cretaceous and Cenozoic. J. Geophys. Res., 97:1391713951.

Clement, B.M., and Robinson, F., 1987. The magnetostratigraphy of Leg 94 sediments. In Ruddiman, W.F., Kidd, R.B., Thomas, E., et al., Init. Repts. DSDP, 94 (Pt. 2): Washington (U.S. Govt. Printing Office), 635-650.

Donnally, D.M., 1989. Calcareous nannofossils of the Norwegian-Greenland Sea: ODP Leg 104. In Eldholm, O., Thiede, J., Taylor, E., et al., Proc. ODP, Sci. Results, 104: College Station, TX (Ocean Drilling Program), 459-486.

Gard, G., and Backman, J., 1990. Synthesis of Arctic and Sub-Arctic coccolith biochronology and history of North Atlantic drift water influx during the last 500,000 years. In Bleil, U., and Thiede, J. (Eds.), Geological History of the Polar Oceans: Arctic versus Antarctic. NATO ASI Ser., Ser. C., $417-436$.

Gartner, S., 1977. Calcareous nannofossil biostratigraphy and revised zonation of the Pleistocene. Mar. Micropaleontol., 2:1-25.

Haq, B.U., 1980. Biogeographic history of Miocene calcareous nannoplankton and paleoceanography of the Atlantic Ocean. Micropaleontology, 26:414-443.

Henrich, R., and Baumann, H.-H. 1994. Evolution of the Norwegian Current and the Scandinavian Ice Sheets during the past $2.6 \mathrm{~m} . \mathrm{y}$.: evidence from ODP Leg 104 biogenic carbonate and terrigenous records. Palaeogeogr., Palaeoclimatol., Palaeoecol., 108:75-94.

Jansen, E., Bleil, U., Henrich, R., Kringstad, L., and Slettemark, B., 1988. Paleoenvironmental changes in the Norwegian Sea and Northeast Atlantic during the last 2.8 m.y.: Deep Sea Drilling Project/Ocean Drilling Program Sites 610, 642, 643, and 644. Paleoceanography, 3:563-581.

Martini, E., 1971. Standard Tertiary and Quaternary calcareous nannoplankton zonation. In Farinacci, A. (Ed.), Proc. 2nd Int. Conf. Planktonic Microfossils Roma: Rome (Ed. Tecnosci.), 2:739-785.

Matsuoka, H., and Okada, H., 1989. Quantitative analysis of Quaternary nannoplankton in the subtropical northwestern Pacific Ocean. Mar. Micropaleontol., 14:97-118.

Müller, C., 1976. Tertiary and Quaternary calcareous nannoplankton in the Norwegian-Greenland Sea, DSDP, Leg 38. In Talwani, M., Udintsev, G., et al., Init. Repts. DSDP, 38: Washington (U.S. Govt. Printing Office), 823-841.

Niitsuma, N., Oba, T., and Okada, M., 1991. Oxygen and carbon isotope stratigraphy at Site 723, Oman Margin. In Prell, W.L., Niitsuma, N., et al., Proc. ODP, Sci. Results, 117: College Station, TX (Ocean Drilling Program), 321-341.

Noritomi, K., Nakamura, R., and Matoba, Y., 1980. Paleomagnetic study of late Cenozoic sediments in Akita prefecture, Japan. J. Min. Coll. Akita Univ. A, 5:1-13.

Raffi, I., Backman, J., Rio, D., and Shackleton, N.J., 1993. Plio-Pleistocene nannofossil biostratigraphy and calibration to oxygen isotopes stratigraphies from Deep Sea Drilling Project Site 607 and Ocean Drilling Program Site 677. Paleoceanography, 8:387-408.

Rio, D., 1982. The fossil distribution of coccolithophore genus Gephyrocapsa Kamptner and related Plio-Pleistocene chronostratigraphic problems. In Prell, W.L., Gardner, J.V., et al., Init. Repts. DSDP, 68: Washington (U.S. Govt. Printing Office), 325-343.

Rio, D., Fornaciari, E., and Raffi, I., 1990. Late Oligocene through early Pleistocene calcareous nannofossils from western equatorial Indian Ocean (Leg 115). In Duncan, R.A., Backman, J., Peterson, L.C., et al., Proc. ODP, Sci. Results, 115: College Station, TX (Ocean Drilling Program), 175-235.

Rio, D., Sprovieri, R., and Thunell, R., 1991. Pliocene-lower Pleistocene chronostratigraphy: a re-evaluation of Mediterranean type sections. Geol. Soc. Am. Bull., 103:1049-1058.

Roth, P.H., 1994. Distribution of coccoliths in oceanic sediments. In Winter, A., and Siesser, W.G. (Eds.), Coccolithophores: Cambridge (Cambridge Univ. Press), 199-218.

Samtleben, C., Schäfer, P., Andruleit, H., Baumann, A., Baumann, K.-H., Kohly, A., Matthiessen, J., Schröder-Ritzrau, A., and 'Synpal' Working Group, 1995. Plankton in the Norwegian-Greenland Sea: from living communities to sediment assemblages-an actualistic approach. Geol. Rundsch., 84:108-136.

Sato, T., 1989. Uppermost Cenozoic coccolith biostratigraphy of Japan [D.Sc. dissert.]. Tohoku Univ., Sendai, Japan. 
Sato, T., Kameo, K., and Takayama, T., 1991. Coccolith biostratigraphy of the Arabian Sea. In Prell, W.L., Niitsuma, N., et al., Proc. ODP, Sci. Results, 117: College Station, TX (Ocean Drilling Program), 37-54.

Sato, T., and Takayama, T., 1992. A stratigraphically significant new species of the calcareous nannofossil Reticulofenestra asanoi. In Ishizaki, K., and Saito, T. (Eds.), Centenary of Japanese Micropaleontology: Tokyo (Terra Sci. Publ.), 457-460.

Sato, T., Takayama, T., Kato, M., Kudo, T., and Kameo, K., 1988. Calcareous microfossil biostratigraphy of the uppermost Cenozoic formations distributed in the coast of the Japan Sea-Part 4: Conclusion. J. Jpn. Assoc. Petrol. Tech., 53:475-491.

Shackleton, N.J., Backman, J., Zimmerman, H., Kent, D.V., Hall, M.A., Roberts, D.G., Schnitker, D., Baldauf, J.G., Desprairies, A., Homrighausen, R., Huddlestun, P., Keene, J.B., Kaltenback, A.J., Krumsiek, K.A.O., Morton, A.C., Murray, J.W., and Westberg-Smith, J., 1984. Oxygen isotope calibration of the onset of ice-rafting and history of glaciation in the North Atlantic region. Nature, 307:620-623.

Shipboard Scientific Party, 1995. Site 910. In Myhre, A.M., Thiede, J., Firth, J.V., et al., Proc. ODP, Init. Repts., 151: College Station, TX (Ocean Drilling Program), 221-270.
, 1995. Site 911. In Myhre, A.M., Thiede, J., Firth, J.V., et al., Proc. ODP, Init. Repts., 151: College Station, TX (Ocean Drilling Program), 271-318.

Takayama, T., and Sato, T., 1987. Coccolith biostratigraphy of the North Atlantic Ocean, Deep Sea Drilling Project Leg 94. In Ruddiman, W.F., Kidd, R.B., Thomas, E., et al., Init. Repts. DSDP, 94 (Pt. 2): Washington (U.S. Govt. Printing Office), 651-702.

Thierstein, H.R., Geitzenauer, K., Molfino, B., and Shackleton, N.J., 1977. Global synchroneity of late Quaternary coccolith datum levels: validation by oxygen isotopes. Geology, 5:400-404.

Whitman, J., and Berger, W.H., 1992. Pliocene-Pleistocene oxygen isotope record, Site 586, Ontong Java Plateau. Mar. Micropaleontol., 18:171198.

Date of initial receipt: 6 July 1995

Date of acceptance: 11 December 1995

Ms 151SR-112 


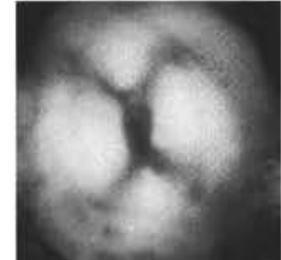

1

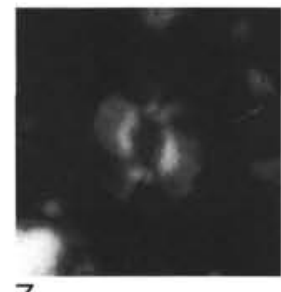

7

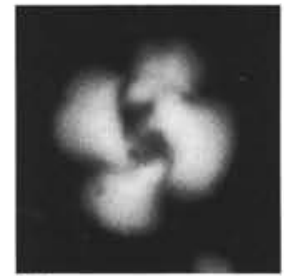

13

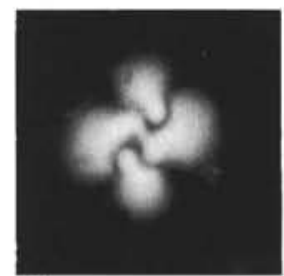

19

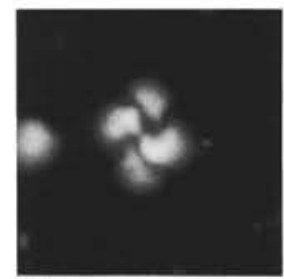

25

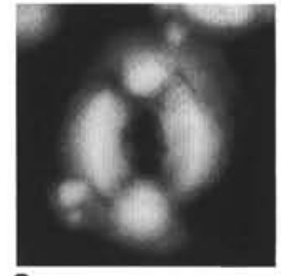

2

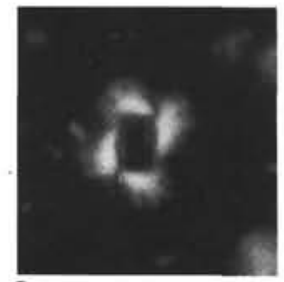

8

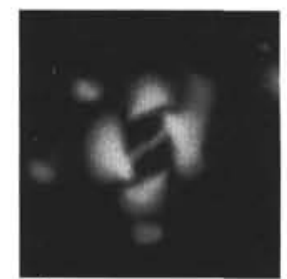

14

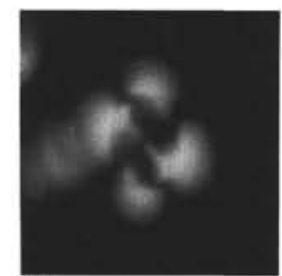

20

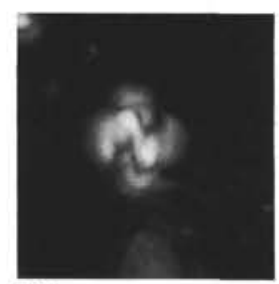

26

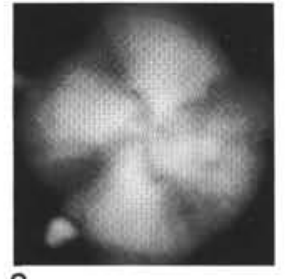

3

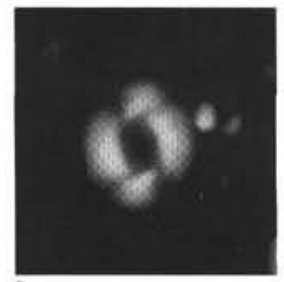

9

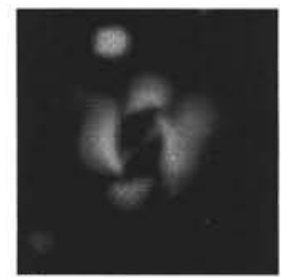

15

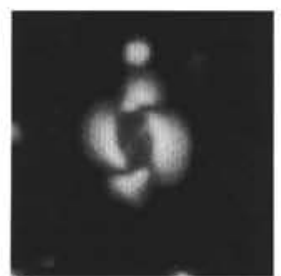

21

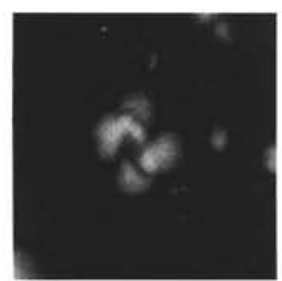

27

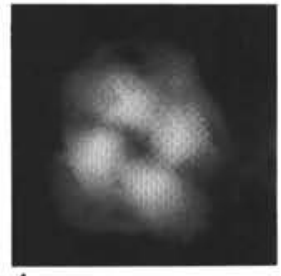

4

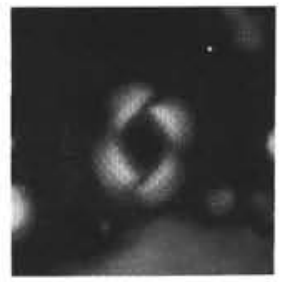

10

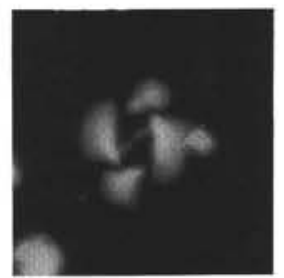

16

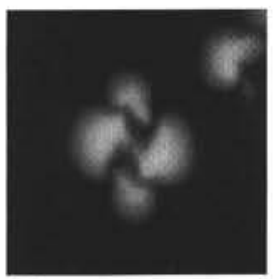

22

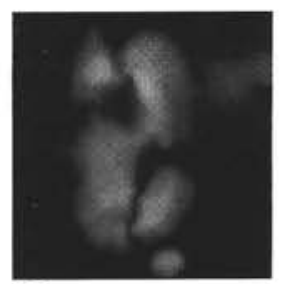

28

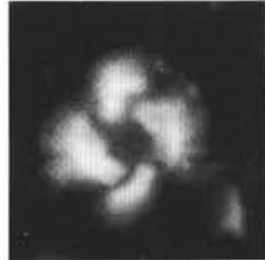

5

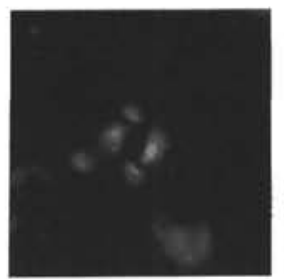

11

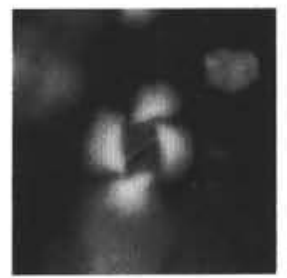

17

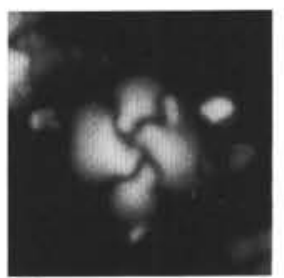

23

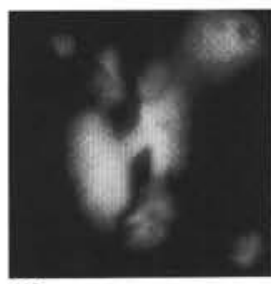

29

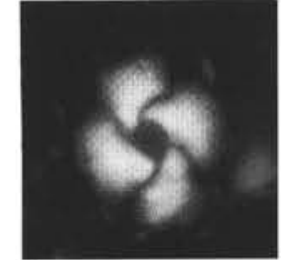

6

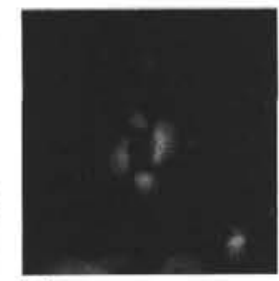

12

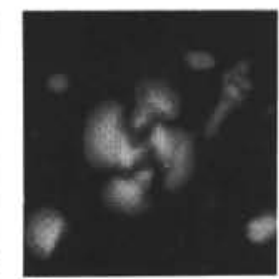

18

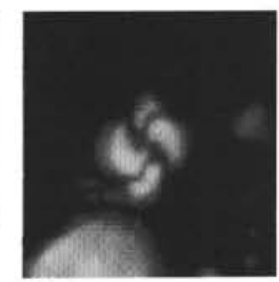

24

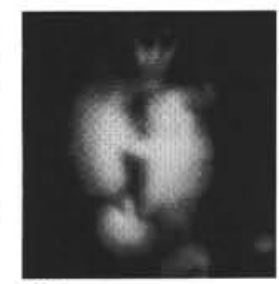

30

\section{$5 \mu$}

Plate 1. 1, 2. Coccolithus pelagicus (Wallich) Schiller; Sample 151-911A-3H-6, 70-71 cm. 3, 4. Calcidiscus leptoporus (Murray and Blackman) Loeblich and Tappan; (3) Sample 151-911A-19X-CC, (4) 151-911A-14H-CC. 5, 6. Reticulofenestra asanoi Sato and Takayama; Sample 151-911A-9H-2, 70-71 cm. 7. Emiliania huxleyi (Lohmann) Hay and Mohler; Sample 151-911A-1H-2, 19-20 cm. 8. Pseudoemiliania lacunosa (Kamptner) Gartner; Sample151-911A-9H-2, 70$71 \mathrm{~cm}$. 9-12. Reticulofenestra spp. (small); Sample 151-911A-9H-2, 70-71 cm. 13. Gephyrocapsa oceanica Kamptner (large); Sample 151-911A-14H-CC. 1418. Gephyrocapsa oceanica Kamptner; Sample 151-911A-19X-CC. 19. Gephyrocapsa caribbeanica Boudreaux and Hay (large); Sample 151-911A-14H-CC. 20-24. Gephyrocapsa caribbeanica Boudreaux and Hay; Sample 151-911A-19X-CC. 25-27. Gephyrocapsa spp. (small); Sample 151-911A-1H-2, 19-20 cm. 28-30. Helicosphaera sellii (Bukry and Bramlette) Jafar and Martini; Sample 151-911A-19X-CC. 